DiRECTEUR DE LA PUBLICATION: Bruno David,

Président du Muséum national d'Histoire naturelle

RÉdACTEUR EN CHEF / EDITOR-IN-CHIEF: Didier Merle

ASSISTANTS DE RÉDACTION / ASSISTANT EDITORS: Emmanuel Côtez (geodiv@mnhn.fr)

Mise EN PAGE / PAGE LAYOUT: Emmanuel Côtez

COMITÉ SCIENTIFIQUE / SCIENTIFIC BOARD:

Christine Argot (MNHN, Paris)

Beatrix Azanza (Museo Nacional de Ciencias Naturales, Madrid)

Raymond L. Bernor (Howard University, Washington DC)

Alain Blieck (chercheur CNRS retraité, Haubourdin)

Henning Blom (Uppsala University)

Jean Broutin (UPMC, Paris)

Gaël Clément (MNHN, Paris)

Ted Daeschler (Academy of Natural Sciences, Philadelphie)

Bruno David (MNHN, Paris)

Gregory D. Edgecombe (The Natural History Museum, Londres)

Ursula Göhlich (Natural History Museum Vienna)

Jin Meng (American Museum of Natural History, New York)

Brigitte Meyer-Berthaud (CIRAD, Montpellier)

Zhu Min (Chinese Academy of Sciences, Pékin)

Isabelle Rouget (UPMC, Paris)

Sevket Sen (MNHN, Paris)

Stanislav Štamberg (Museum of Eastern Bohemia, Hradec Králové)

Paul Taylor (The Natural History Museum, Londres)

COUVERTURE / COVER:

Left specimen: Hebertides jurassica Guinot, De Angeli \& Garassino, 2007, in dorsal view; Right specimen: Xantho cf. moldavicus (Yanakevich, 1977), in outer lateral view; Background: Panoramic view of the Museum quarry 'la carrière-musée' (Channay-sur-Lathan).

Geodiversitas est indexé dans / Geodiversitas is indexed in:

- Science Citation Index Expanded (SciSearch $\left.{ }^{\circledR}\right)$

- ISI Alerting Services ${ }^{\circledR}$

- Current Contents ${ }^{\circledR} /$ Physical, Chemical, and Earth Sciences ${ }^{\circledR}$

- Scopus ${ }^{\circledR}$

Geodiversitas est distribué en version électronique par / Geodiversitas is distributed electronically by:

- BioOne ${ }^{\circledR}$ (http://www.bioone.org)

Les articles ainsi que les nouveautés nomenclaturales publiés dans Geodiversitas sont référencés par /

Articles and nomenclatural novelties published in Geodiversitas are referenced by:

- ZooBank ${ }^{\circledR}$ (http://zoobank.org)

Geodiversitas est une revue en flux continu publiée par les Publications scientifiques du Muséum, Paris Geodiversitas is a fast track journal published by the Museum Science Press, Paris

Les Publications scientifiques du Muséum publient aussi / The Museum Science Press also publish:

Adansonia, Zoosystema, Anthropozoologica, European Journal of Taxonomy, Naturae, Cryptogamie sous-sections Algologie, Bryologie, Mycologie.

Diffusion - Publications scientifiques Muséum national d'Histoire naturelle

CP $41-57$ rue Cuvier F-75231 Paris cedex 05 (France)

Tél. : 33 (0)1407948 05 / Fax: 33 (0)14079 3840

diff.pub@mnhn.fr / http://sciencepress.mnhn.fr

(C) Publications scientifiques du Muséum national d'Histoire naturelle, Paris, 2019

ISSN (imprimé / print): 1280-9659/ ISSN (électronique / electronic): 1638-9395 


\title{
An appraisal of the Middle-Late Miocene fossil decapod crustaceans of the 'Faluns' (Anjou-Touraine, France)
}

\author{
Àlex OSsó \\ Llorenç de Vilallonga, 17B, 1er-1 ${ }^{\mathrm{a}}$, 43007 Tarragona (Catalonia) \\ aosso@comt.cat (corresponding author) \\ Cyril GAGNAISON \\ UniLaSalle - Terre \& Sciences (site de Beauvais) \\ B2R19 rue Pierre Waguet - BP30313 - F-60026 Beauvais cedex (France)
}

Submitted on 6 August 2018 | accepted on 12 December 2018 | published on 25 April 2019

KEY WORDS

Decapoda,

Brachyura,

Paratethys,

Mediterranean,

Miocene,

Faluns.

MOTS CLÉS

Decapoda,

Brachyura,

Paratéthys,

Méditerranée,

Miocène,

Faluns.

urn:Isid:zoobank.org:pub:32E3623C-C47B-4D42-B2EB-E2594D031349

Ossó À. \& Gagnaison C. 2019. - An appraisal of the Middle-Late Miocene fossil decapod crustaceans of the 'Faluns' (Anjou-Touraine, France). Geodiversitas 41 (9): 367-383. https://doi.org/10.5252/geodiversitas2019v41a9. http:// geodiversitas.com $/ 41 / 9$

\section{ABSTRACT}

A detailed report of the decapod crustaceans discovered in the Middle-Late Miocene outcrops of the 'Faluns' of Anjou-Touraine (West of France) is here presented. The Couffon's compendium (1908) is reviewed, and the systematics updated. A total of seven genera and eight species of eubrachyuran crabs, undetermined chelae, and one anomuran species, are reported. The varied decapod assemblage, dominated by Pilumnus mediterraneus (Lőrenthey, 1897), shows clear affinity with coeval decapod faunas from the Mediterranean and Paratethys realm. This fauna dwelt in a shallow warm and agitated environment of bryozoan meadows. The age of Hebertides jurassica Guinot, De Angeli \& Garassino, 2007, is confirmed, and the probable provenance of the holotype is suggested. We also discuss the generic status of Scylla michelini A. Milne-Edwards, 1861 transferred herein to Necronectes A. MilneEdwards, 1881.

\section{RÉSUMÉ}

Évaluation des crustacés décapodes fossiles du Miocène moyen-supérieur des 'Faluns' (Anjou-Touraine, France). Une présentation détaillée d'une série de crustacés décapodes provenant de différents affleurements des faluns du Miocène moyen-supérieur de l'Anjou-Touraine (ouest de la France) est présentée dans cet article. Un total de sept genres et huit espèces d'eubrachyures et une espèce d'anomure sont décrits ici. Cet assemblage de décapodes est varié, dominé par Pilumnus mediterraneus (Lőrenthey, 1897), montrant une affinité claire avec les faunes de décapodes contemporaines de la Mer Méditerranée et du domaine paratéthysien. Cette faune vivait dans un environnement peu profond, chaud et agité, dans des prairies à bryozoaires. L'âge de Hebertides jurassica Guinot, De Angeli \& Garassino, 2007 est confirmé, et la provenance éventuelle de l'holotype est ici suggérée. Le statut générique de Scylla michelini A. Milne-Edwards, 1861 est discuté et transféré à Necronectes A. Milne-Edwards, 1881. 


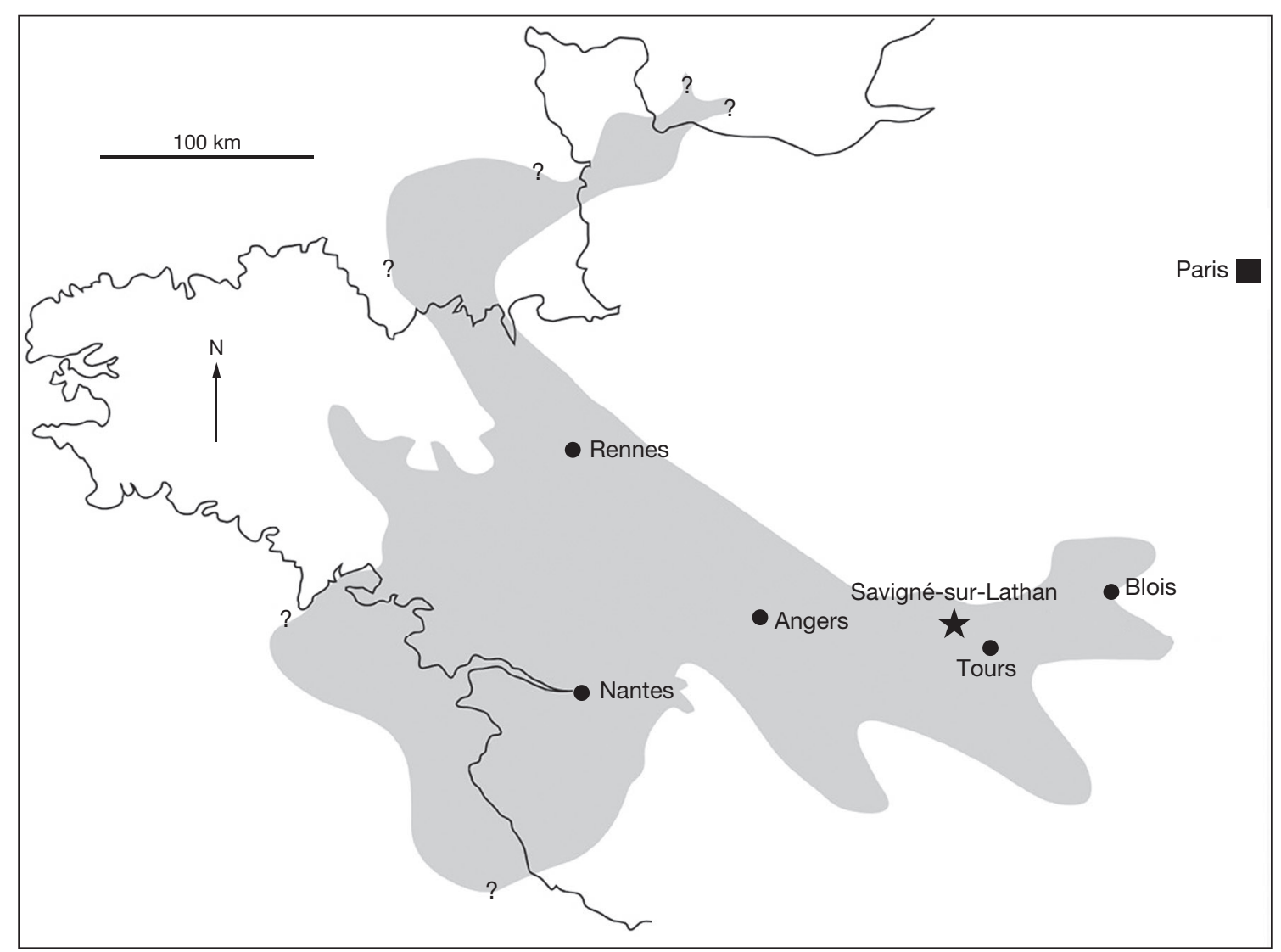

FIG. 1. - Location map of the outcrops area, and extension of the Falun's Sea during the Middle-Late Miocene (shaded area). Map from Gagnaison et al. 2012. ?, limits of the "Faluns sea" probable extension.

\section{INTRODUCTION}

Since Couffon (1908, 1934), little has been written on the crustaceans of the Miocene of the 'Faluns' of Anjou-Touraine (France). Couffon (1908), summarized the known species of decapods found in the 'Faluns' up to that time: Scylla michelini A. Milne-Edwards, 1861, Maja orbignyana Millet de la Turtaudière, 1865, Titanocarcinus pulchellus A. Milne-Edwards, 1864, Cancer deshayesii A. Milne-Edwards, 1865 (sic), Cancer sismondai Meyer, 1843 (sic) and also reported fragments of dactyli as Neptunus aff. monspeliensis A. Milne-Edwards, 1864 (sic). Herein, that work is reviewed and the systematics discussed and updated. Gagnaison (2012) described Paguristes gagnaisoni (Fig. 5E) from the Middle Miocene of 'La Sonneterie' quarry, Meigné-le-Vicomte (Anjou, France).

As a result of excavations carried out by J. C. Gagnaison and J. P. Hartmann, in 'La Sonneterie' quarry, between 1993 to 1997 , one hundred and thirty-five disarticulated decapod crustacean remains, mainly chelae, fragments of carapaces, and a few complete dorsal carapaces, were recovered after sieving the bioclastic sands. From this assemblage, and from other collections recovered in different quarries of this region, eight families of decapods, containing seven genera and eight species of brachyurans, are identified: Calappa praelata Lörenthey in Lőrenthey \& Beurlen, 1929; Calappa sp. (Calappidae De Haan,
1833); Hebertides jurassica Guinot, De Angeli \& Garassino, 2007 (Corystidae Samouelle, 1819); Maja orbignyana (Majidae Samouelle, 1819); Pilumnus mediterraneus (Lőrenthey, 1897) (Pilumnidae Samouelle, 1819); Liocarcinus sp. (Polybiidae Ortmann, 1893); Necronectes michelini (Portunidae Rafinesque, 1815); Xantho cf. X. moldavicus (Yanakevich, 1977) (Xanthidae MacLeay, 1838), several undetermined brachyuran chelae, and the anomuran Paguristes gagnaisoni Gagnaison, 2012 (Paguridae Latreille, 1802). From these, an array of twenty-three specimens, the best preserved of each species, are described and figured herein. The assemblage is clearly dominated by Pilumnus mediterraneus (Lőrenthey, 1897), the most abundant species in the 'Faluns', whereas other species are represented by unique specimens.

The present work represents a complete overview of the fossil decapods recovered in the 'Faluns' outcrops of Anjou-Touraine expanding our knowledge of several aspects of the assemblage. For instance, the age and the probable area of occurrence of Hebertides jurassica is suggested, the systematic placement of Scylla michelini is rehabilitated, and the true nature of Titanocarcinus pulchellus is discussed.

The specimens described in the present work are housed in the collections at the Musée du Savignéen (Savigné-surLathan, Indre-et-Loire, France), under acronym MS, and the paleontological collections of UniLaSalle Polytechnic Institute (Beauvais, Oise, France) under acronym ULB. 


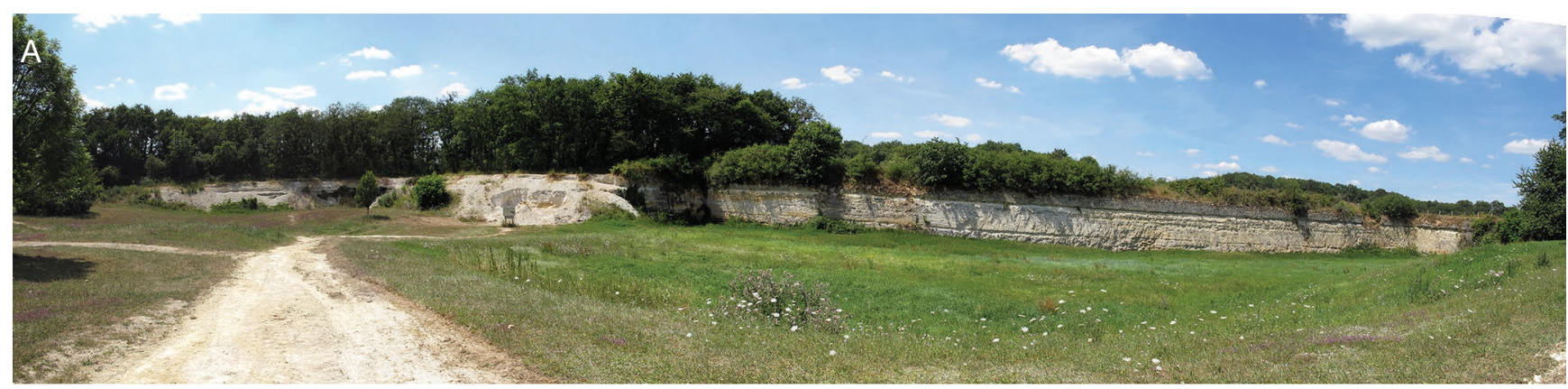

B

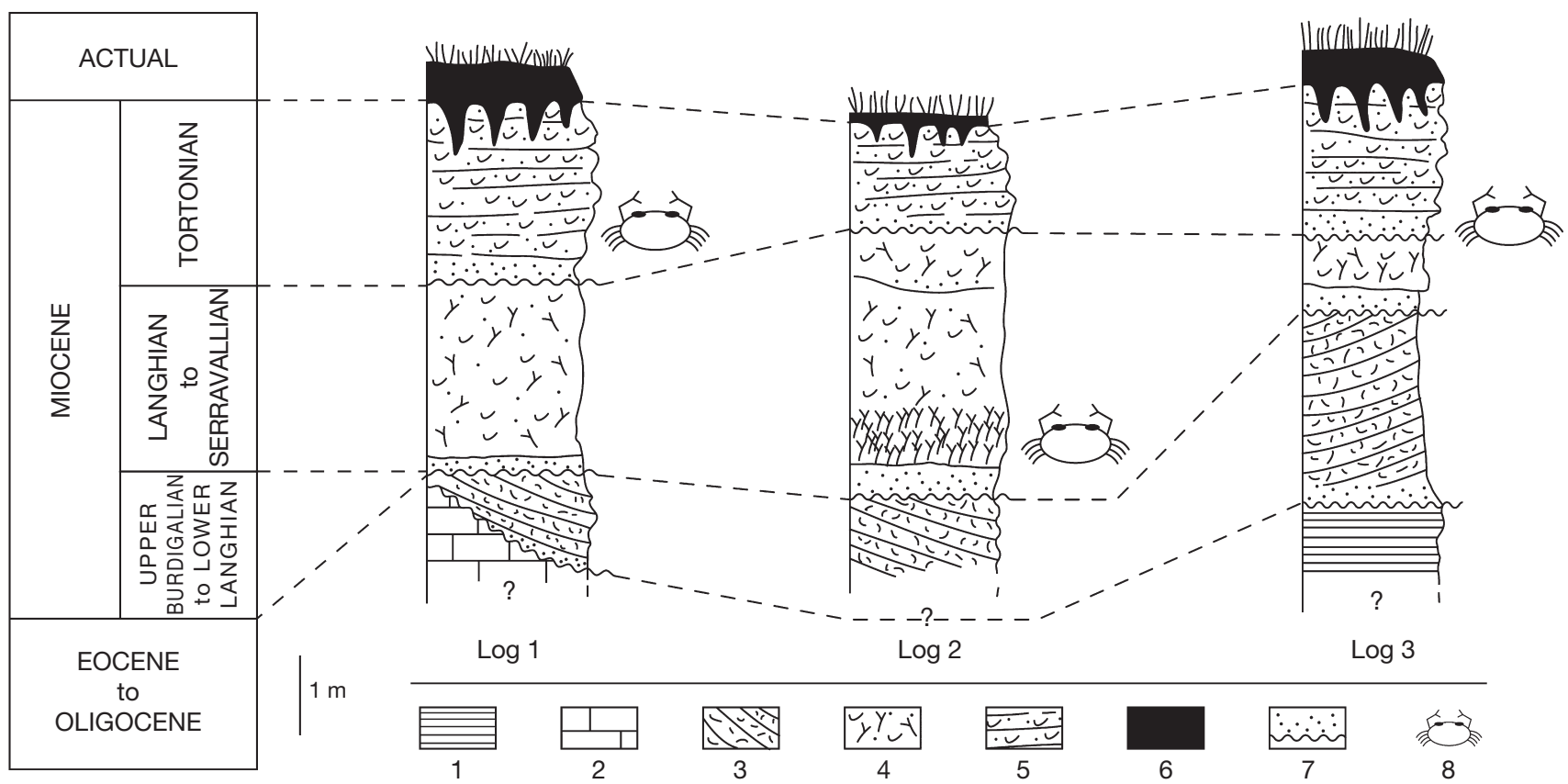

FIG. 2. - A, Panoramic view of the Museum quarry 'la carrière-musée' (Channay-sur-Lathan); B, lithostratigraphic columns from the differents shelly sands quarries. Log 1, 'la carrière-musée' (Channay-sur-Lathan, Indre-et-Loire); Log 2, 'La Sonneterie' (Meigné-le-Vicomte, Maine-et-Loire); Log 3, 'Les Bournais' (St-Laurentde-Lin, Indre-et-Loire). Cells: 1, Eocene green marl; 2, Oligocene limestone; 3, clinostratified calcarenite (Upper Burdigalian to Lower Langhian); 4, Bryozoans clayey shelly sands, 'Savignean facies' (Langhian to Serravallian); 5, Bioclastic calcarenite with Anadara turonica (Tortonian); 6, modern soils (Quaternary-Actual); 7, Miocene erosive surface; $\mathbf{8}$, Fossil occurrences. Photograph by A. Ossó; drawing by C. Gagnaison.

\section{LOCATION AND STRATIGRAPHY.}

The specimens studied herein were recovered from different localities around Savigné-sur-Lathan (Indre-et-Loire, France) (Fig. 1).

Between the late Burdigalian and the Tortonian (Miocene), the transgressing sea in the Loire Valley (from West to East until the Blésois region) and the Savigné-sur-Lathan/Noyantsous-le-Lude (South-West of the Paris Basin, Anjou-Touraine) deposited shelly, sandy sediments locally named 'Faluns' (Lecointre 1947) (Fig. 1). This sedimentary formation is found in different French regions: Vendée-Bretagne, Poitou, Normandy, Anjou-Touraine and Blésois (Temey 1996).

Excavations in these deposits locally reveal the presence of numerous marine fossils invertebrates and vertebrates. These Miocene shelly sands were deposited over different PaleogeneEarly Miocene continental formations: Eocene green marl, Oligocene-Agenian lacustrine limestone, and Orlanian fluvial sands (Gagnaison 2017; Gagnaison et al. 2018). Quaternaryrecent soils cover all the Tertiary formations (Fig. 2). Three Miocene marine facies are present in the sedimentary basin of Savigné-sur-Lathan/Noyant-sous-le-Lude: 1) clinostratified calcarenite with sea urchins (late Burdigalian-early Langhian); 2) the clayey shelly sands with bryozoans ('Savignean facies') of the Langhian-Serravallian; and 3) the bioclastic calcarenite with the Tortonian Anadara turonica ('Lublean facies') (Courville \& Bongrain 2003).

The fossils reported and described herein were recovered from two facies: the clayey shelly sands with bryozoans (Langhian-Serravallian) and the bioclastic calcarenite with Anadara turonica shells (Tortonian) (Fig. 2).

The clayey shelly sands with bryozoans (Langhian-Serravallian), also called 'Savignean facies':

Its thickness varies between 0.5 to 5 meters (Fig. 2). These facies are composed of clayey, shelly sand with many bryozoan fragments (mainly celleporiforms and reteporiforms) and 
molluscs shells (Buge 1948; Courville \& Bongrain 2003). Most of the decapod specimens reported here, come from the lower part of these shelly sand ('La Sonneterie' quarry near Meigné-le-Vicomte; Fig. 2). In this quarry, this geological formation begins with many bryozoan bioconstructions in place or slightly broken. Many fragile invertebrate fossils have been found in these facies such as molluscs with their connecting valves, sea urchins with their spines, and wellpreserved crab remains. This biotope integrates into a warm underwater environment typical of shallow (upper infralittoral) bryozoan colonies (Gagnaison 2012). The classic clay shelly sand with bryozoan debris and oblique strata covers this bioconstruction. This unit is interpreted as a warm and shallow infralittoral environment (Gagnaison 2012),

The bioclastic calcarenite with Anadara turonica (Tortonian):

Corresponds to the last Miocene formation in this sedimentary basin. The facies is visible in all three quarries of this study (Fig. 2). Its thickness does not exceed 4 meters and its top is always marked by Quaternary-Recent brown clays dissolution pockets (Fig. 2). This calcarenite is composed by rolled and broken fossils (bryozoans, molluscs, echinoderms and marine vertebrates) and rolled quartz grains. Many oblique bi-directional strata are visible on all the outcrops. Several of the crustacean remains reported herein, come from the base of this formation. This calcarenite is interpreted as a warm sea of shallow depth (intertidal) very agitated by underwater currents (Temey 1996).

\begin{tabular}{ll}
\multicolumn{2}{l}{ ABBREVIATIONS } \\
L & length; \\
W & width; \\
FOW & fronto-orbital width; \\
H & height; \\
T & thick.
\end{tabular}

\section{SYSTEMATIC PALAEONTOLOGY}

Order DECAPODA Latreille, 1802 Infraorder BRACHYURA Latreille, 1802 Section EUBRACHYURA de Saint Laurent, 1980 Subsection HETEROTREMATA Guinot, 1977

Superfamily CALAPPOIDEA De Haan, 1833 Family Calappidae De Haan, 1833

\section{Genus Calappa Weber, 1795}

Type SPECIES. - Cancer granulatus Linnaeus, 1758, subsequent designation by Latreille (1810).

Calappa praelata Lőrenthey in Lőrenthey \& Beurlen, 1929 (Fig. 3A-C)

Calappa praelata Lőrenthey in Lőrenthey-Beurlen, 1929: 132, 133 , pl. 6, fig. 3. - Glaessner 1929: 71. - Müller 1984a: 66, pl. 35 , figs 1-2, 7; pl. 36, fig. 6; 1984b: pl. 2, fig. 4; 1996: 9, pl. 1, fig. 11; 1998: 22. - Gatt \& De Angeli 2010: 1329, pl. 2, fig. 2. - Schweitzer et al. 2010: 83. — Pasini et al. 2012: 135-140, fig. 1A-C. Collins 2014: 37-36, t. 1, pl. 2, fig. 9. — Díaz-Medina et al. 2017: 180, 181, fig. 9A-C.
Calappa heberti-Glaessner 1928: 174, 175. — Veiga Ferreira 1958: 203-207, text-figs 1-3, pl. 1, figs 1-3 (non Brocchi, 1883).

Calappa cf. heberti - Da Carvalho 1959: 79, pl. 2, figs 4-6.

Calappa heberti sp. 2 - Bachmayer 1962: 41, pl. 2, fig. 1.

Calappa aff. granulata - Bachmayer 1962: 42.

Calappa aff. heberti-Förster 1979: 255, 257, pl. 1, figs 2, 3 (non fig. 4).

Calappa sp. - Artal \& Gilles 2007: fig. 2a.

Carapace de crabe - Gagnaison et al. 2009: 1, fig. 2.

Material eXAmined AND MEASUREMENTS (in mm). - Complete dorsal carapace embedded of bioclastic limestone, cuticle preserved, MS2006 FS 134a: $\mathrm{L}=30, \mathrm{~W}=39.5, \mathrm{FOW}=13$.

Locality AND horizon. - 'La Sonneterie' quarry, Meigné-leVicomte (Maine-et-Loire). 'Savignean facies', Langhian-Serravallian (Middle Miocene).

\section{DESCRIPTION}

Carapace medium sized, transversely subovate in outline, expanded clypeiform process (wing-like extension) in posterolateral angles; wider than long, maximum width at posterolateral angle; strongly vaulted longitudinally and transversely. Cuticle well preserved. Maximum width at level of third posterolateral tooth. Front narrow, medial notch; orbits small, rounded; supraorbital margin entire. Anterolateral margin strongly arcuate, ornate with blunt teeth and nodes. Posterolateral margin strongly convex; wing-like extension with largest tooth at posterolateral angle, preceded by three teeth progressively smaller, and followed by two teeth that decrease in size progressively; all of them triangular with an axial elevated ridge. Posterior margin short, slightly convex, bounded by two blunt teeth. Carapace surface covered anteriorly by large tubercles and swellings, smaller posteriorly, forming longitudinal rows. Central regions bounded longitudinally by two parallel grooves running from orbits to cardiac region. Ventral parts and appendages not present.

\section{REMARKS}

The carapace outline, toothed posterolateral wing-like extension, and dorsal features of the 'Faluns' specimen, fit well with the description and images of the holotype figured by Müller (1984a: 66, pl. 35, figs 1-2), as well as with the specimens in literature, widely described and depicted by diverse authors through time (see for instance the synonymies list above). Further, comparisons with specimens of the collection of the first author (AO), allow us to place the French specimen within this species with confidence. Differences of the French specimen with Calappa heberti Brocchi, 1883 from the Middle Miocene of the Paratethys are clear, since the dorsal surface of the carapace of $C$. heberti is ornate with short squamous ridges in the posterior portion and have less produced teeth in its posterolateral angle (e.g. Lőrenthey in Lőrenthey \& Beurlen 1929: pl. 6, fig. 3; Müller 1984a: pl. 35, figs 1-2, 7; pl. 36, fig. 6). It differs as well with C. saheliensis Van Straelen, 1937, from the Late Miocene of North Africa and Southern Iberian Peninsula, in having large tubercles in the anterior half of carapace and by the absence of longitudinal grooves, more or less marked, in the branchial regions 


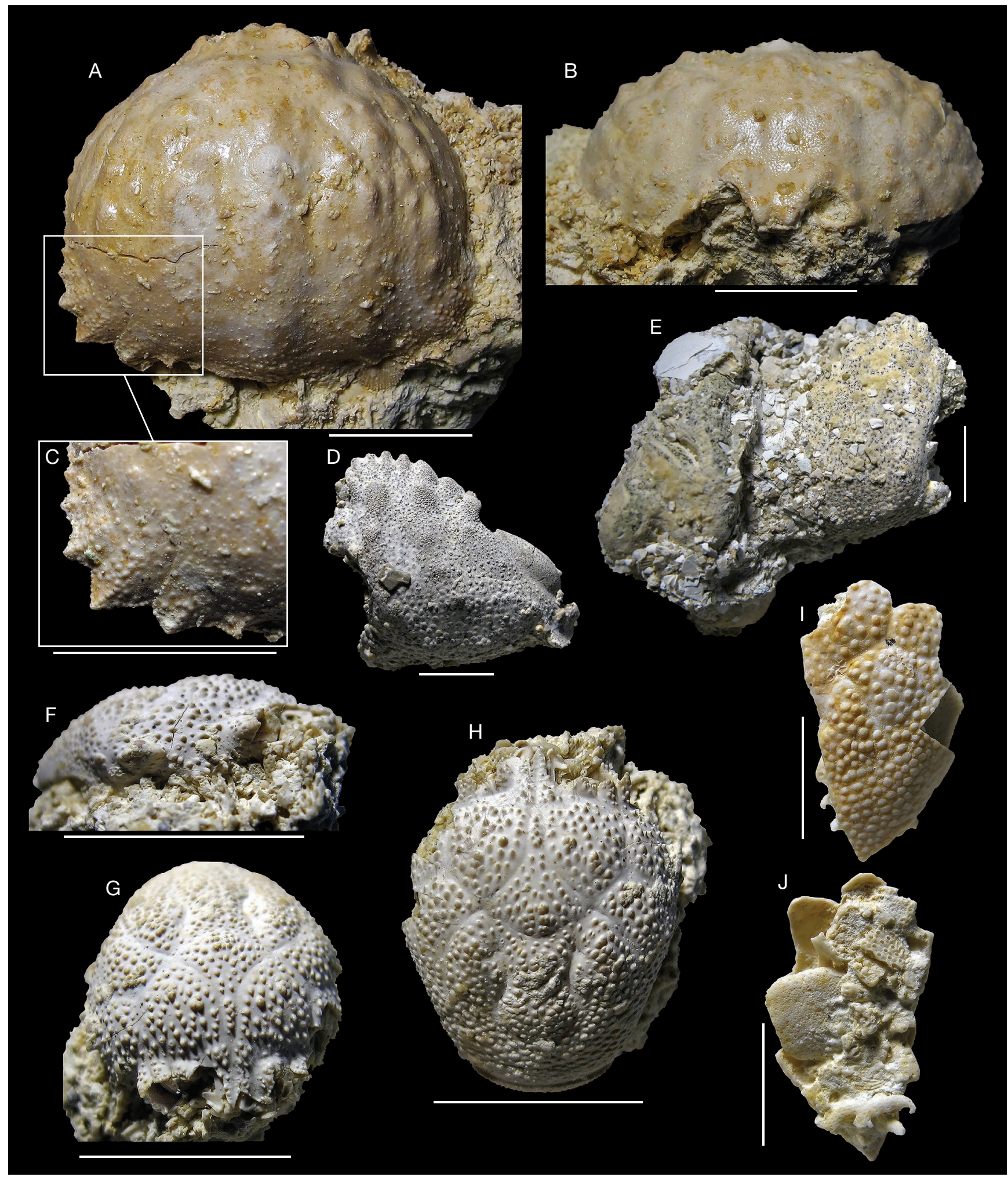

FiG. 3. - A-C, Calappa praelata Lőrenthey in Lőrenthey \& Beurlen, 1929, MS2006 FS 134a: A, dorsal view; B, frontal view; C, close-up of posterolateral margin; D, E, Calappa sp., MS2018-2-1: D, left chela, MS2018-2-2; E, right chela; F-J, Hebertides jurassica Guinot, De Angeli \& Garassino, 2007; F-H, MS2018-1-1: F, right lateral view; G, frontal view; H, dorsal view; I, J, ULB-SO-1: I, fragment of right dorsal carapace; J, the same fragment showing bryozoans incrusted. Scale bars: A-H, $10 \mathrm{~mm} ; \mathrm{I}, \mathrm{J}, 5 \mathrm{~mm}$. Photographs by À. Ossó.

(Van Straelen 1937: pl. 32, fig. 1; type series from MNHN: MNHN.F.R03768). Calappa zurcheri Bouvier, 1899 from the Oligocene-Miocene of Mexico and Panama, also differs clearly from the studied specimen in having stronger tuberculation along almost all the dorsal carapace surface (e.g. Bouvier 1899: 189-192 text-fig. 1; Luque et al. 2017: fig. 12M). 
Calappa praelata is widespread during the Miocene along the Paratethys and Proto-Mediterranean; it is also present in the Atlantic along the southern coast of Portugal. Díaz-Medina et al. (2017: 181) summarized the known previous records of this species. Calappa praelata is morphologically very close to the extant C. granulata, mainly dorsally; however, different features in chelae and in the posterior margin distinguish both species (see Müller 1984a: pl. 36, figs 1-5).

\section{Calappa sp.}

(Fig. 3D, E)

MATERIAL EXAMINED AND MEASUREMENTS (in mm). - Two palms of a right (embedded in shell-grit matrix) and a left chelipeds, dactyli not preserved. Right chela, MS2018-2-1: $\mathrm{H}=28$; left chela, MS2018-2-2: $\mathrm{H}=30.5 ; \mathrm{W}=33 ; \mathrm{T}=8.5$.

LOCALITY AND HORIZON. - 'La carrière-musée' (Channay-surLathan, Indre-et-Loire). Bioclastic calcarenite with Anadara turonica, Tortonian (Late Miocene).

\section{DESCRIPTION}

Palm subtrapezoidal, much higher distally. Upper margin strongly convex distally, cockscomb like; armed with six to eight teeth, being the distal ones acute and the medial ones blunt and larger. Lower margin straight, sharp edged. Outer surface of palm with coarse granules in the lower half, being smaller and tight in the upper half.

\section{REMARKS}

The two described chelae were recovered on a different stratigraphic level (Tortonian) than the Calappa praelata carapace described above (Languian-Serravallian), which does not allow us to assign with certainty those chelae to that species. They could be likely attributable to C. praelata, but the dense granulation of the outer surface of the palm differs from the less ornamented surface of the right chela figured by Müller (1984a: pl. 36, fig. 6) and attributed to C. praelata. The granules that stipple the outer surface of the palm, the shorter teeth of the upper margin of chelae, and the unrimmed lower margin precludes the attribution of the 'Faluns' chelae to C. granulata (see Müller 1984a: pl. 36, fig. 1). Consequently, we prefer to leave these chelae as Calappa sp.

Superfamily CoRYsTOIDEA Samouelle, 1819

Family CORYSTIDAE Samouelle, 1819

Subfamily CORYSTINAE Samouelle, 1819

Genus Hebertides

Guinot, De Angeli \& Garassino, 2007

Type species. - Hebertides jurassica Guinot, De Angeli \& Garassino, 2007 by original designation.
Hebertides jurassica Guinot, De Angeli \& Garassino, 2007 (Fig. 3F-J)

Hebertides jurassica Guinot, De Angeli \& Garassino, 2007b: 241260, fig. 1-3. - Van Bakel et al. 2009: 80. - Schweitzer et al. 2010: 104. - Taylor et al. 2012: 71-83, fig. 1; - Taylor 2012: 9-11, fig. 2. — Jagt et al. 2015: 882. — Emmerson 2017: 323.

Corystid - Guinot et al. 2007a: 53-55, fig. 1.

Material EXAMINED AND MEASUREMENTS (in $\mathrm{mm}$ ). - Carapace, MS2018-1-1: $\mathrm{L}=16.5, \mathrm{~W}=13, \mathrm{FOW}=13 .-$ Fragment of carapace, ULB-SO-1: $\mathrm{L}=11.4 ; \mathrm{W}=5.8$.

LOCALITY AND HORIZON. - Carapace: 'La carrière-musée' (Channay-sur-Lathan, Indre-et-Loire). Bioclastic calcarenite with Anadara turonica, Tortonian (Late Miocene). Fragment of carapace: 'La Sonneterie' quarry, Meigné-le-Vicomte (Maine-et-Loire). 'Savignean facies', Langhian-Serravallian (Middle Miocene).

DESCRIPTION (modified from Guinot et al. 2007b)

Carapace longitudinally ovate, longer than wide, convex in both sections; maximum width at the epibranchial teeth level; W/L ratio about 0.75 . Cuticle well preserved. Regions relatively well defined, slightly swollen and separated by weak, smooth grooves; medial regions faintly distinct, forming a continuous medial area. Dorsal surface of carapace covered by rounded tubercles in anterior half, grouped and aligned in posterior half. Front narrow, broken, medially $\mathrm{V}$-notched. Orbits broad; inner orbital tooth blunt, as a fold; supraorbital margin sinuous, finely serrated, with two V-shaped fissures; outer orbital tooth triangular, acute, prominent. Supraorbital area slightly depressed, smooth. Anterolateral margin convex, with three granular teeth (excluded the extraorbital one); the second sunken, placed at lower level that the rest; the third the larger; the fourth the smallest. Posterolateral margin slightly convex. Posterior margin convex, with marked granular rim. Protogastric regions slightly swollen, with two tubercles obliquely aligned at each lobe. Mesogastric region subpentagonal, slender and elongate anteriorly, broad posteriorly. Metagastric region indistinct from mesogastric region. Urogastric region subrectangular elongate, separated from meso-, metagastric regions by two gastric pits. Cardiac region subhexagonal, somewhat raised respect to urogastric region. Meta-, urogastric and cardiac regions, bounded laterally by well-marked branchiocardiac groove. Intestinal region indistinct. Hepatic region subtriangular, well delimited by cervical and hepatic groove. Branchial regions slightly swollen, epiand mesobranchial lobes delimited by a weak oblique groove. Ventral parts and appendages not present.

\section{REMARKS}

Hebertides jurassica was erected based on a unique specimen found as a loose block in a quarry of Ranville (Normandy). In spite of the strikingly fine preservation of the specimen, its age was considered as the same as the rocks of the quarry, i.e., Bathonian (Middle Jurassic) (Guinot et al. 2007a, b). Further examination of the matrix of this specimen revealed that the bryozoans (mainly cheilostomes) attached to the matrix and specimen were not Jurassic in age but younger, 
Cenozoic, and probably Miocene in age. Therefore, it was assumed that the specimen was accidentally discarded in the quarry by a fossil collector. Thus, the provenance of that specimen remained unknown (Taylor 2012; Taylor et al. 2012).

Despite this, complete specimens of Hebertides jurassica are known among French collectors' private collections, which regularly collect in the 'Faluns' of Anjou-Touraine. Fragmentary remains of their carapaces are relatively common among the typical shell grit of the 'Faluns' (Fig. 3I-J). Therefore, the common occurrence of $H$. jurassica in the 'Faluns' leads us to suggest that, likely, the holotype comes from a locality in this region whose age is confirmed as Middle-Late Miocene.

Superfamily MaJOIDEA Samouelle, 1819

Family MAJIDAE Samouelle, 1819

Subfamily MajinaE Samouelle, 1819

Genus Maja Lamarck, 1801

TyPE SPECIES. - Cancer squinado Herbst, 1788, subsequent designation by ICZN (1958).

Maja orbignyana Millet de la Turtaudière, 1865 (Fig. 4A-F)

Maia orbignyana Millet de la Turtaudière, 1865: 577. — Millet 1854: 152 (nomen nudum). — Couffon 1934: 171, fig. 155.

Maja orbignyana-Couffon 1908: 2, 3, pl. 1, figs 1-4. - Glaessner 1929: 247.

Maja orbigniana - Couffon 1910: 130, fig. 4. - Schweitzer et al. 2010: 95.

Maia sp. - Via 1932: 9.

Maia cfr. orbingyana - Vía 1941: 118, 119, pl. 10, fig. 70.

Maja cf. orbigniana - Müller 1993: 13, fig. 6E.

Material eXAMined AND MEASUREMENTS (in $\mathrm{mm}$ ). - One fragment of anterior part of carapace preserving left rostral spine, left orbit and protogastric lobe, MS2012 0 172a: $\mathrm{L}=26.3$; W $=21$. Three fragments of left orbital region, ULB-SO-3: $\mathrm{L}=9.5, \mathrm{~W}=16$; ULB-SO-3: $\mathrm{L}=17, \mathrm{~W}=11$; ULB-SO-2: $\mathrm{L}=19, \mathrm{~W}=14.5$. Merus of ambulatory leg ULB-SO-4: $\mathrm{L}=23$; $\mathrm{W}=5$. - Dactylus of ambulatory leg ULB-SO-5: $\mathrm{L}=21 ; \mathrm{W}=4$.

LOCALITY AND HORIZON. - 'La Sonneterie' quarry, Meigné-leVicomte (Maine-et-Loire). 'Savignean facies', Langhian-Serravallian (Middle Miocene).

\section{DESCRIPTION}

Rostrum bifid with long, conical and acute rostral spines. Orbits shallow, rounded, opened; supraorbital margin with medial, flattened, acute subtriangular tooth, bounded by two fissures, the outer one deepest; outer orbital tooth long, conical, acute, slightly upward directed; inner orbital tooth subtriangular, acute; infraorbital margin with a blunt, prominent inner tooth, separated from the outer lateral orbit margin by a deep fissure. Protogastric region strongly swollen, ornate with strong and raised rounded tubercles. Hepatic region slightly swollen, ornate with rounded granules, the biggest ones at the basis of the hepatic spine, which is conical, acute and laterally directed. Merus of ambulatory leg subcircular in cross section, slightly compressed laterally; dactylus of ambulatory leg conical, subcircular in proximal cross section, slightly compressed distally.

\section{REMARKS}

The recovered specimens are fragmentary portions of the left anterior parts of several carapaces (mainly orbits and front). After comparison with images of the holotype (Couffon 1908: figs 1, 2, 4; 1934: pl. 1, fig. 155), and of the fragmentary left orbit figured there (Couffon 1908: pl. 1, fig. 3), it is clear that the recovered remains can be attributed to $M$. orbignyana with confidence. The strong, rounded and raised tubercles in the protogastric lobe and hepatic region are distinctive for the species (see Müller 1993: 13).

Superfamily PILUMNOIDEA Samouelle, 1819

Family Pilumnidae Samouelle, 1819

Subfamily PILUMninae Samouelle, 1819

$$
\text { Pilumnus Leach, } 1815
$$

TyPE SPECIES. - Cancer hirtellus Linnaeus, 1761, by monotypy.

$$
\text { Pilumnus mediterraneus (Lőrenthey, 1897) }
$$

Pilodius mediterraneus Lörenthey, 1897: 160, 167, 169; 1898a: 105, 113 , 115; 1898b: 126-129, pl. 8, figs 5, 6; 1898c: 99-101, pl. 8, figs 5, 6. - Glaessner 1929: 315.

Pilumnus sp. - Glaessner 1928: 190.

Chlorodopsis mediterraneus - Lörenthey in Lörenthey \& Beurlen 1929: 34, 225-227, pl. 12, figs 13-17, 19.

Chlorodopsis mediterranea - Bachmayer 1953a: 253, pl. 3, fig. 5. Bachmayer \& Tollmann 1953: 314.

'Pilodius' mediterraneus - Müller 1974a: 122, pl. 3, fig. 3.

Pilumnus mediterraneus - Müller 1974b: 280; 1976a: 510; 1976b: 152; 1979: 274, pl. 21, fig. 3; 1984a: 93-94, pl. 87, figs 2-5, pl. 88, figs 1-5. - Radwański et al. 2006: 96, pl. 2, fig. 7. - Ossó \& Stalennuy 2011: 37, fig. 9.3. — Górka et al. 2012: 171. — Górka in Wysocka et al. 2016: 379, fig. 14E.

Pilumnus sp. - Förster 1979: 260-261, pl. 3, fig. 6, pl. 5, fig. 1, 3, text-figs 8,9 .

Pince d'une patte de crabe - Gagnaison et al. 2009: 1, fig. 3.

Pilumnus cfr. P. mediterraneus - De Angeli et al. 2011: 112, fig. 4.

MATERIAL EXAMINED AND MEASUREMENTS (in mm). - Two complete dorsal carapaces with cuticle well preserved, ULB-SO-6: $\mathrm{L}=19.5$, $\mathrm{W}=27, \mathrm{~F}=8, \mathrm{FOW}=15.5$; $\mathrm{MS} 20120170: \mathrm{L}=14, \mathrm{~W}=20, \mathrm{~F}=$ $8, \mathrm{FOW}=13.5$. - Two right chelae, ULB-SO-7: $\mathrm{H}=8.72, \mathrm{~W}=$ 15.6; ULB-SO-8: $\mathrm{H}=7.84$; $\mathrm{W}=12.8$. 
LOCAliTy AND HORIZON. — 'La Sonneterie' quarry, Meigné-leVicomte (Maine-et-Loire). 'Savignean facies', Langhian-Serravallian (Middle Miocene).

\section{DESCRIPTION}

Carapace relatively small sized, subhexagonal, longitudinally vaulted anteriorly, regions faintly marked; surface smooth, weakly ornate with small acute granules and small clusters of acute granules of squamous aspect, spread mainly by anterior half of carapace; setal pits visible. Maximum width at level of fourth anterolateral tooth, at the anterior half of carapace. Front bilobed, medially notched, each half with inner lobes very wide, and the outer lobes smaller, and separated from the inner orbital angle by notches. Orbits small, subrectangular, complete, forward directed; supraorbital margin finely serrated, with two fissures, one median and a second close to outer orbital tooth. Anterolateral margin with four subtriangular teeth (excluding outer orbital tooth), the first one semifused with the outer orbital one, the second one broad, the third and fourth acute. Posterolateral margin slightly convex, smooth. Posterior margin clearly convex medially, rimmed. Frontal region with a short, longitudinal deep groove, lobes slightly swollen. Gastric process fairly defined. Epigastric lobes faintly swollen, ornate. Protogastric lobes rounded, swollen, faintly ornate. Mesogastric region subpentagonal elongated anteriorly, wider posteriorly. Metagastric region indistinct. Urogastric region slightly depressed and separated from meso- and metagastric lobes by two gastric pits. Cardiac region diamond shaped, weakly swollen. Intestinal region narrow, transversely elongate, faintly swollen laterally. Hepatic region with a short granulate ridge paralleling the anterolateral margin. Epibranchial region with a short, acute, half-moon ridge not reaching the fourth (epibranchial) anterolateral tooth. Meso- and metabranchial regions indistinct, swollen. Gastrohepatic groove well marked; cervical and branchiocardiac grooves slightly marked. Thoracic and abdominal features not preserved. Right chela stout, palm slightly wider than long, outer side smooth, spiny in the upper margin and the distal portion of palm, mainly in smaller individuals; articulation with the dactylus strong; dactyli stout, about one third of propodus length; dactylus curved with blunt teeth in occlusal margin; pollex strong, with three to four massive acute teeth in the occlusal margin; setal pits visible in both dactyli. Carpus stout, angle of upper and outer surface with scattered spiny tubercles; upper inner angle with prominent tooth.

\section{REMARKS}

The specific assignation of the French specimens to Pilumnus mediterraneus is unequivocal, in view of their stout, short palm with spiny upper margin and distal part, as well as their short dactyli (cf. Müller 1984a: 94, pl. 87, figs 2-5, pl. 88, figs 1-5; Radwański et al. 2006: fig. pl. 2, figs 7A, B; Ossó \& Stalennuy 2011: fig. 9.3). Couffon (1908: 4, pl. 2, figs 5-7) reported a fragment and complete carapace and referred them to Titanocarcinus pulchellus (currently Haydnella pulchellus (A. Milne-Edwards, 1864)) and reproduced the diagnosis and the figures of the type of Milne-Edwards (Couffon 1908: pl. 2, figs 5a-5b). The type specimen was found on the 'Faluns' of Maine-et-Loire, and is currently lost (Couffon 1908: 1; Müller 1984a: 90). Strikingly, the diagnosis of $H$. pulchellus (see A. Milne-Edwards 1864: 33, 34), as well as its small size, fits well with that of $P$. mediterraneus. Given the abundance of chelae of $P$. mediterraneus in the 'Faluns' outcrops, it would be plausible that the small carapace described by A. Milne-Edwards as T. pulchellus was likely a specimen of $P$. mediterraneus. Since the transfer of this species from Titanocarcinus to Haydnella was made based on the drawings of A. Milne-Edwards (see Müller 1984a: 90; Schweitzer et al. 2007: 281, t. 1, fig. 1I), we suggest a revision of the systematic status of this taxon.

Pilumnus mediterraneus is by far the most abundant brachyuran of the 'Faluns' outcrops, in view of the great number of chelae remains found; although, complete carapaces, or even fragments of them, are very scarce. Müller (1984a: 94) pointed out already, referring to the Central Paratethys realm, that this species "is probably the most common crab in the Badenian [Langhian/Serravallian]. It occurs in all types of studied biotopes, even in reefs, but it is the most abundant in very shallow, almost eulittoral environments", and stated: "P. mediterraneus occurs in all substages of the Badenian". It is present, furthermore, in the Proto-Mediterranean during the Late Miocene, in the Messinian reefal outcrops of Spain and Italy (e.g. De Angeli et al. 2011). As stated by Müller (1984a: 94), P. mediterraneus is very close morphologically to the extant $P$. hirtellus Linnaeus, 1761 that lives in the Eastern Atlantic and Mediterranean Sea. We concur.

\section{Superfamily PORTUNOIDEA Rafinesque, 1815 \\ Family CARCINIDAE Macleay, 1838 \\ Subfamily PolYBinae Ortmann, 1893}

Genus Liocarcinus Stimpson, 1871

TyPe SPECIES. - Portunus holsatus Fabricius, 1798, by original designation.

\section{Liocarcinus sp.}

(Fig. 5A, B)

Material EXAMINED AND MEASUREMENTS (in mm). - Partially preserved carapace, MS2012 $0172 \mathrm{~b}: \mathrm{L}=10.5, \mathrm{~W}=12$, FOW $=$ $8.5, \mathrm{~F}=4$.

LOCALITy AND HORIZON. - 'La Sonneterie' quarry, Meigné-leVicomte (Maine-et-Loire). 'Savignean facies', Langhian-Serravallian (Middle Miocene).

\section{DESCRIPTION}

Small sized carapace, subhexagonal, smooth, slightly wider than long. Regions weakly defined. Three longitudinally aligned tubercles at each side of carapace. Front incomplete, straight, but appears to be slightly produced medially. Orbits 


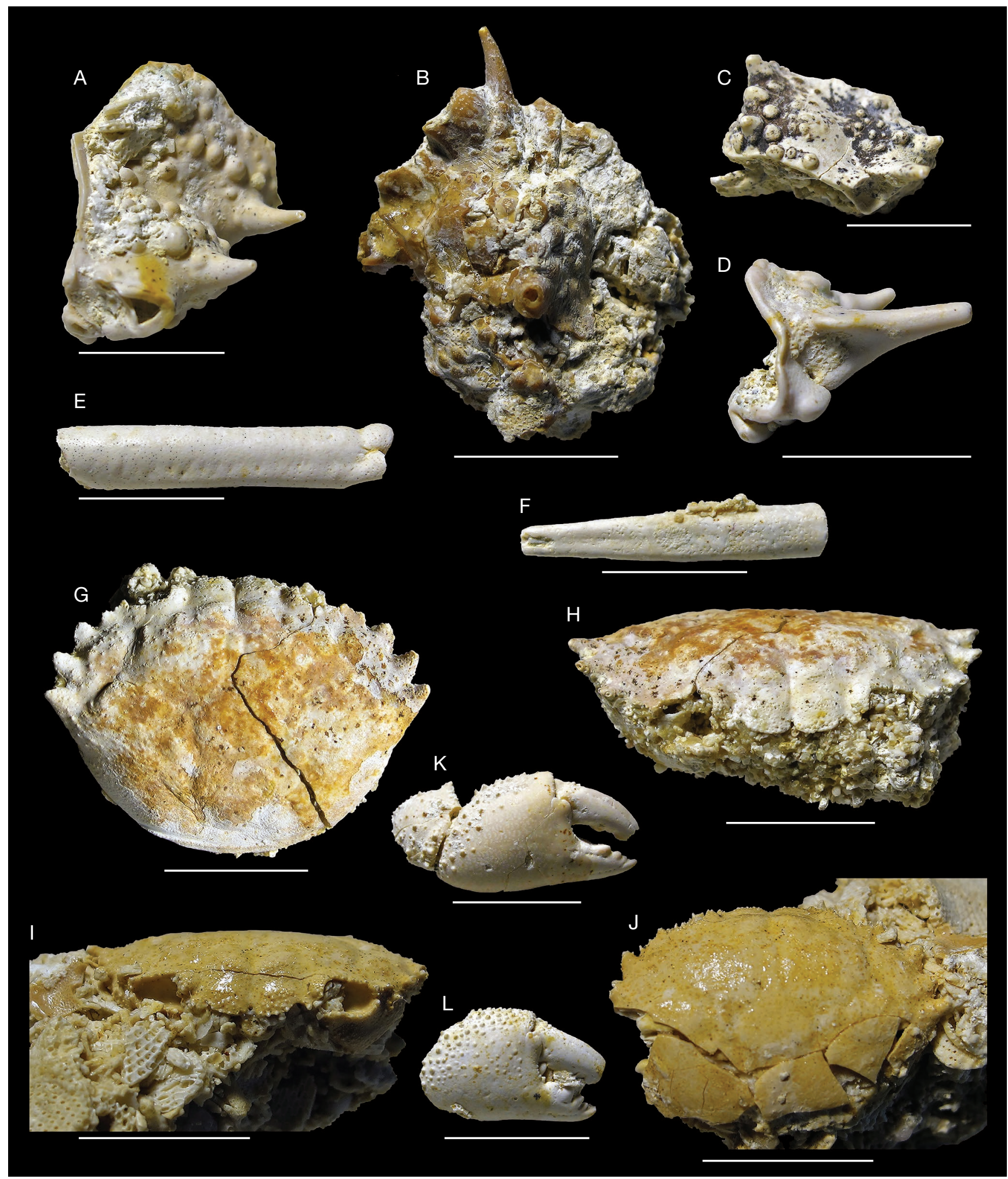

FIG. 4. - A-F, Maja orbignyana Millet de la Turtaudière, 1865: A, ULB-SO-2, frontal view of left orbit; B, MS2012 0 172a, dorsal view of anterior part of carapace; C, ULB-SO-3, frontal view of left orbit; D, ULB-SO-3, frontal view of left orbit; E, ULB-SO-4, merus of ambulatory leg; F, ULB-SO-5, dactylus of ambulatory leg; G-L, Pilumnus mediterraneus (Lőrenthey, 1897): G, ULB-SO-6, dorsal view; H, frontal view; I, MS2012 0 170, frontal view; J, dorsal view; K, ULB-SO-7, left chela; L, ULB-SO-8, left chela. Scale bars: $10 \mathrm{~mm}$. Photographs by À. Ossó.

relatively large; supraorbital margin with two closed fissures. Anterolateral margin slightly arcuate, with four subtriangular teeth (excluding the outer orbital tooth), the last of them (epi- branchial tooth) the sharper. Posterolateral margin straight; reentrant of fifth pereiopod well marked. Posterior margin straight. Frontal region smooth, flattened. Gastric process poorly 
defined. Epigastric lobes slightly marked. Protogastric lobes slightly swollen with faintly marked transverse ridge at each lobe; marked tubercle near gastrohepatic groove. Mesogastric region weakly marked. Urogastric region depressed. Cardiac region large, slightly swollen. Intestinal region depressed. Hepatic region depressed. Epibranchial region sigmoidal, weakly marked, with medial tubercle. Mesobranchial region slightly swollen, with marked tubercle, Metabranchial region depressed. Cervical groove faintly marked. Branchiocardiac groove weakly marked. Ventral parts and appendages not preserved.

\section{REMARKS}

The features of the studied specimen fit with those of Liocarcinus, and its general outline matches well with the known Miocene Liocarcinus species (see Schweitzer et al. 2010). However, they differ in having a most decorated or rough surface of the carapace, as for instance $L$. rakosensis Lörenthey in Lörenthey \& Beurlen, 1929 and L. kuehni (Bachmayer, 1953), whereas in the studied specimen the carapace surface is completely smooth; or in having more marked and raised regions as in the case of $L$. oroszyi (Bachmayer, 1953) and L. praearcuatus Müller, 1996 (see Bachmayer 1953a: pl. 2, figs 2, 5-5a; Müller 1984a: 83-84, pl. 69, figs 2-6, pl. 71, figs 1-4; 1996: 10, pl. 2, figs 2-3). Liocarcinus ottnangensis (Bachmayer, 1953) differs clearly in having a trifid front and a characteristic prominent transverse ridge running across the mesogastric and epibranchial regions, which is absent in the studied specimen (see Hyžný et al. 2015). Liocarcinus oligocenicus (Paucă, 1929) and L. lancetidactylus (Smirnov, 1929) present a different pattern of anterolateral margins and front, furthermore, their poor preservation makes difficult an accurate comparison (e.g. Jerzmańska 1967: fig. 1; Schweitzer et al. 2009: fig. 6; and Garassino \& Novati 2001, respectively).

Regarding the extant species of Liocarcinus (see $\mathrm{Ng}$ et al. 2008), they have usually a more arched anterolateral margins than the studied specimen, and most of them have a trifid front, and/or a rough surface of carapace, which is smooth in the studied specimen. Liocarcinus pusillus (Leach, 1815) and L. navigator (Herbst, 1794) have a similar blunt front medially produced, similar to the studied specimen, but they differ in having a rougher dorsal surface, and by the lack of the conspicuous protogastric ridges and three characteristic tubercles, longitudinally aligned, present in the French specimen possess (e.g. Froglia \& Manning 1982; Koch \& Duriš 2016)

The general outline and dorsal sculpture of the studied specimen also resemble that of Miopipus pygmaeus (Brocchi, 1883) (Brocchi 1883: 1, pl. 5, figs 4-4a). However, Müller (1984a: 84, pl. 72, figs 1-4), described the front of $M$. pygmaeus as trilobed, narrow and prominent, and the carapace regions as strongly inflated, which precludes a congeneric relationship with the specimen described herein.

Therefore, in spite that the aforementioned differences could lead us to propose a new species of Liocarcinus for this specimen, based on the poorly preserved sole specimen, we report it as Liocarcinus sp., until more specimens are available for study.
Family PORTUNIDAE Rafinesque, 1815

Subfamily NeCronectinae Glaessner, 1928

Genus Necronectes A. Milne-Edwards, 1881

TYPe SPECIES. - Necronectes vidalianus A. Milne-Edwards, 1881 by original designation.

Necronectes michelini (A. Milne-Edwards, 1861)

(Fig. 5D-F)

Scylla michelini A. Milne-Edwards, 1861: 137, pl.3., figs 3-3A. Couffon 1908: 3, 4, pl. 1, figs 6-10, pl. 2, figs 1, 2. - Schweitzer et al. 2006: 122; 2010: 110. - Karasawa et al. 2008: 106. — Emmerson 2017: 584.

Cancer macrochelus - Millet 1854: 152 (non Desmarest, 1817).

Scylla cf. michelini - Glaessner 1928: 184, 185.

Scylla? michelini-Glaessner 1929: 374.

Scylla sp. (cf. michelini) - Lörenthey \& Beurlen 1929: 178, pl. 15, figs 5,6 .

Necronectes michelini - Glaessner 1933: 5-6. — De Angeli \& Marangon 1992: 178, 179.

Scylla michelini? - Betancort et al. 2014: 345, pl. 1, figs K1-K2 (non I1-I2)

Material eXAMINED AND MEASUREMENTS (in mm). - Two dactyli. Right dactylus, ULB-SO-9: $\mathrm{L}=41.38, \mathrm{H}=25$. - Left dactylus (tip broken off), ULB-SO-10: $\mathrm{L}=32.53, \mathrm{H}=15.52$.

LOCALITY AND HORIZON. - 'La Sonneterie' quarry, Meigné-leVicomte (Maine-et-Loire). 'Savignean facies', Langhian-Serravallian (Middle Miocene).

\section{DESCRIPTION}

Right dactylus stout, gently curved forward; subrectangular in section with rounded upper angles; strong proximal knobstick molariform tooth followed by six serial rounded conical teeth of different sizes; rounded tip. Left dactylus stout, gently curved forward; subrectangular in section with rounded upper angles, proximal tooth and tip not preserved.

\section{REMARKS}

Scylla michelini was erected based on fragmentary chelipeds and was referred to Scylla De Haan, 1833, because of its similarity to the strong chelipeds of the extant $S$. serrata (Forskål, 1775). Nevertheless, A. Milne-Edwards (1861: 136), pointed out the absence in $S$. michelini of the two typical distinct spines on the distal upper part of the palm, near the insertion of dactylus (see Couffon 1908: pl. 1, figs 6-10, t. 2, figs 1, 2; MNHN.F.B25950, which are present in Scylla species (e.g. Keenan et al. 1998; Trivedi \& Vachhrajani 2013). Rathbun (1918: 168), when described Necronectes proavitus (as Gatunia proavita), pointed out as well, the absence of those spines as a differential trait with Scylla, and also noted the striking similarity between the cheliped of $N$. proavitus and that of $S$. michelini (Rathbun 1918: 171). Furthermore, A. Milne-Edwards (1861: 136) noted as well, that the upper 


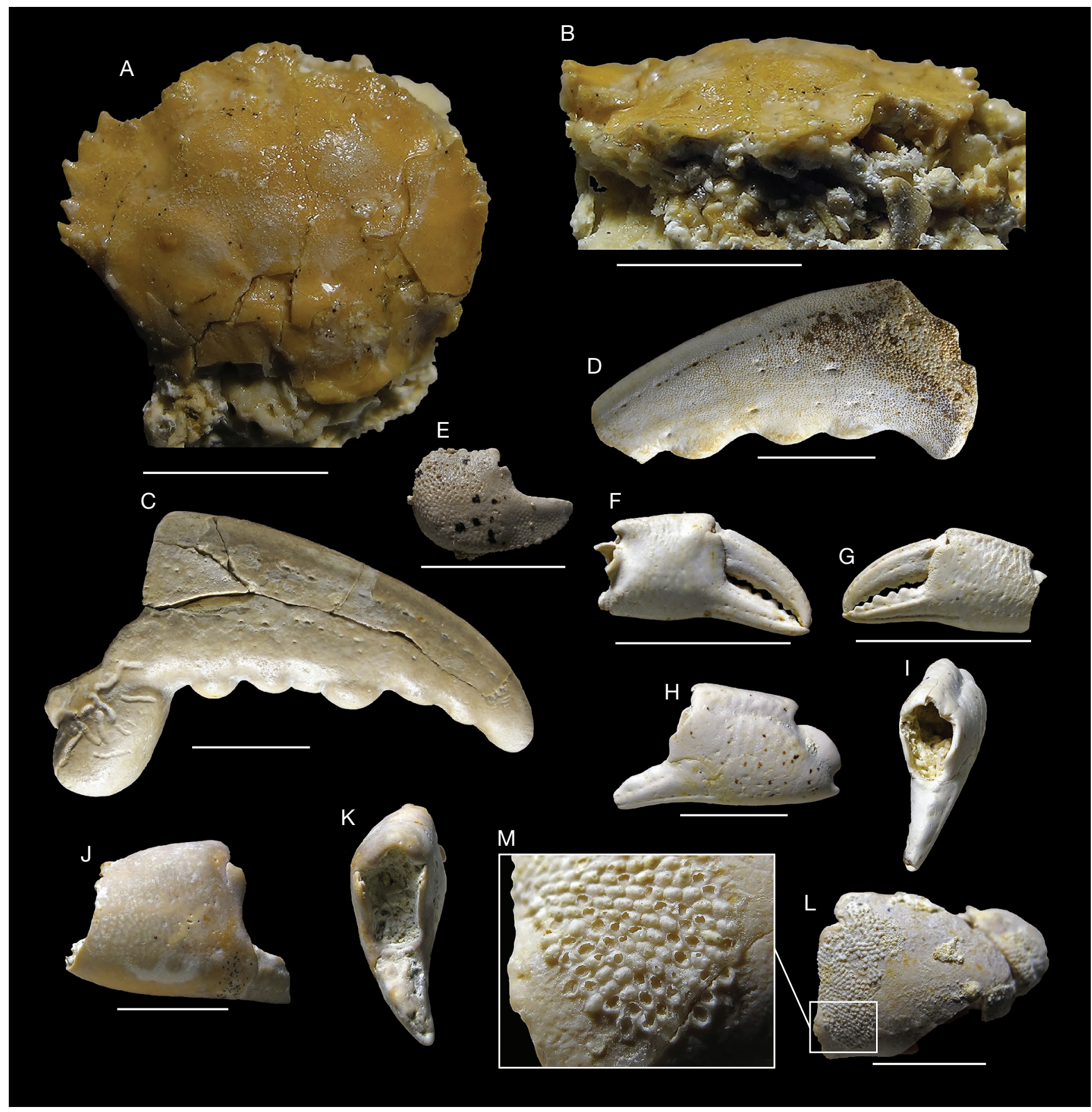

FiG. 5. - A, B, Liocarcinus sp., MS2012 0 172b: A, dorsal view; B, frontal view; C, D, Necronectes michelini (A. Milne-Edwards, 1861): C, ULB-SO-9, right dactylus; D, ULB-SO-10, left dactylus; E, Paguristes gagnaisoni Gagnaison, 2012, MS2006 FS 134b, right chela; F-I, Xantho cf. moldavicus (Yanakevich, 1977): F, ULB-SO-11, left chela, inner lateral view; G, outer lateral view; H, ULB-SO-12, left chela, outer lateral view; I, frontolateral view; J-M, undetermined chelae: J, ULB-SO-13, lateral view of right chela; K, frontal view; L, ULB-SO-14, lateral view of left chela; M, close-up showing an encrusted colony of bryozoans. Scale bars: A, B, $5 \mathrm{~mm}$; C-M, $10 \mathrm{~mm}$. Photographs by À. Ossó.

margin of the palm of $S$. michelini is rounded, whereas it is usually more flattened and angled in Scylla species (see Keenan et al. 1998: fig. 8).

Subsequently, several authors assigned similar fragmentary remains of dactyli y to Scylla michelini (see synonym list). Glaessner (1933: 5), included S. michelini within Necronectes A. Milne-Edwards, 1881, being followed by De Angeli \& Marangon (1992: 178, 179). Nevertheless, this placement was questioned by Schweitzer et al. (2006: $121,122)$, which retained $S$. michelini within Necronectes (see also Karasawa et al. 2008: 106).

The aforementioned differences in the palms, such as the absence of the outer and inner spines on distal margin, and the strong spine at carpal articulation of propodus, further, the absence of spines on the outer part of carpus, peculiar of the most species of Scylla possesses (e.g. Keenan 
et al. 1998: fig. 8; Trivedi \& Vachhrajani 2013: fig. 5a-c), allow us to confirm the generic placement of $S$. michelini within Necronectes, as it was previously placed by Glaessner (1928, 1933).

\author{
Superfamily XANTHOIDEA MacLeay, 1838 \\ Family XANTHIDAE MacLeay, 1838 \\ Subfamily XANTHINAE MacLeay, 1838
}

Genus Xantho Leach, 1814

TYPE SPECIES. - Cancer incisus Leach, 1814 by monotypy.

Xantho cf. moldavicus (Yanakevich, 1977) (Figs 5F-I)

Material EXAMined AND MEASUREMENTS (in $\mathrm{mm}$ ). - Two left chelae, ULB-SO-11: $\mathrm{L}=6, \mathrm{~W}=12$; ULB-SO-12: $\mathrm{L}=11$, $\mathrm{W}=21.5$.

LOCALITY AND HORIZON. - 'La Sonneterie' quarry, Meigné-leVicomte (Maine-et-Loire). 'Savignean facies', Langhian-Serravallian (Middle Miocene).

\section{DESCRIPTION}

Propodi transversely elongate, stout. Palm of left propodus subtrapezoidal, slightly wider than high; maximum height at the distal end. Upper margin straight, flattened, rugose. Lower margin gently convex. Outer side convex, with longitudinal rugose ridges; transverse stepped depression parallel to the upper margin, about to the three quarters of the total height. Inner side obliquely convex distally and concave in the upper proximal corner. Dactyli slightly shorter than palm; dactylus gently curved downwards with a blunt keel in upper margin, and occlusal margin with six or seven subequal triangular teeth; pollex straight, stout, lower margin slightly convex, transverse lateral keel and groove, with occlusal margin with seven or eight subtriangular teeth, the biggest ones in the middle. Tip of both dactyli spoon like. Setal pits visible.

\section{REMARKS}

We have not found carapace remains of Xantho moldavicus among the recovered decapod remains in the 'Faluns' outcrops, though the specimen figured by Couffon (1908: pl. 2, fig. 6) as Titanocarcinus pulchellus could to be referred to this species. In any case, the chelae examined match exactly the chelae of $X$. moldavicus described and depicted in the literature (e.g. Müller 1984a: pl. 86, figs 5-8, pl. 86, figs 3, 5; Ossó \& Stalennuy 2011: fig. 9, 1-2; Górka in Wysocka et al. 2016: fig. $14 \mathrm{G}$ ). Furthermore, the typically spooned occlusal surface of the dactyli tips, would allow us to assign, those chelae to the aforementioned species. A successful search of this specimen in the museum collections would confirm the assignation of both, the Couffon's carapace and the chelae reported herein to $X$. moldavicus. Meanwhile, in absence of complete carapaces, or remnants of them, with which to relate the chelae, we prefer to leave them in open nomenclature.

\section{Undetermined chelae}

(Fig. 5J-M)

Material eXAMINED AND MEASUREMENTS (in mm). — Left chela palm, ULB-SO-14: $\mathrm{L}=14.5, \mathrm{~W}=17$. - Right chela palm: ULBSO-13: $\mathrm{L}=14, \mathrm{~W}=20$.

LOCALITY AND HORIZON. - 'La Sonneterie’ quarry, Meigné-leVicomte (Maine-et-Loire). 'Savignean facies', Langhian-Serravallian (Middle Miocene).

\section{DESCRIPTION}

Propodi with massive palm slightly subtrapezoidal, stout, higher distally; outer and inner surface convex, completely smooth. Upper and lower margin rounded, smooth. Pollex broken, appears short, with flattened molariform teeth. Carpus rounded, smooth; blunt tooth at upper inner angle.

\section{REMARKS}

Due to their incompleteness and the lack of dactyli, or carapaces to they may be related, a generic or familial assignation is not clear. However, in view of the features displayed, they could belong to Carpilioidea or Xanthoidea but even to other superfamilies as well.

\section{DISCUSSION}

Couffon (1908), made a compendium of all of the species found and described from the 'Faluns' of Anjou-Touraine. He revisited the species formerly described by A. Milne-Edwards and Millet de la Turtaudière, housed in the collections of the museums of Angers and Paris, likewise, he reported and described new specimens. In his work, Couffon used in part the original diagnosis of the authors and made his own observations.

For instance, he reported three specimens of Titanocarcinus pulchellus (Fig. 6A-D), of which he could not locate the type species; consequently, he figured the original drawings of A. Milne-Edwards (1863: t. 9, figs 2, 2a;). With respect to the first specimen, based mainly on the diagnosis not on the drawing, which may be somewhat idealized (Couffon 1908: t. 2, figs 5, 5a; Fig. 6A, B), we suggest, as indicated above, that this specimen is likely a specimen of Pilumnus mediterraneus. The second specimen reported and also attributed to T. pulchellus (Couffon 1908: t. 2, fig. 7; Fig. 6C) is a fragment. Based on that figure, we are not able to attribute it to any genus or species. The third specimen attributed to this species (Couffon 1908: t. 2, fig. 6; Fig. 6D), an almost complete dorsal carapace, could actually be, as previously mentioned, a specimen of Xantho moldavicus (cf. Müller 1984a: pl. 86, figs 1, 2, 4; Ossó \& Stalennuy 2011: fig. 3.11-12), a species to which we tentatively attribute the chelae (Fig. 3F-I).

Two chelae were also reported in Couffon's work. One of them, a complete right cheliped without size references (Couffon 1908: t. 2, figs 3-4; Fig. 6E-F), was attributed to Lobocarcinus sismondai (as Cancer sismondae). In our opinion, the general shape of this cheliped and the length and denti- 


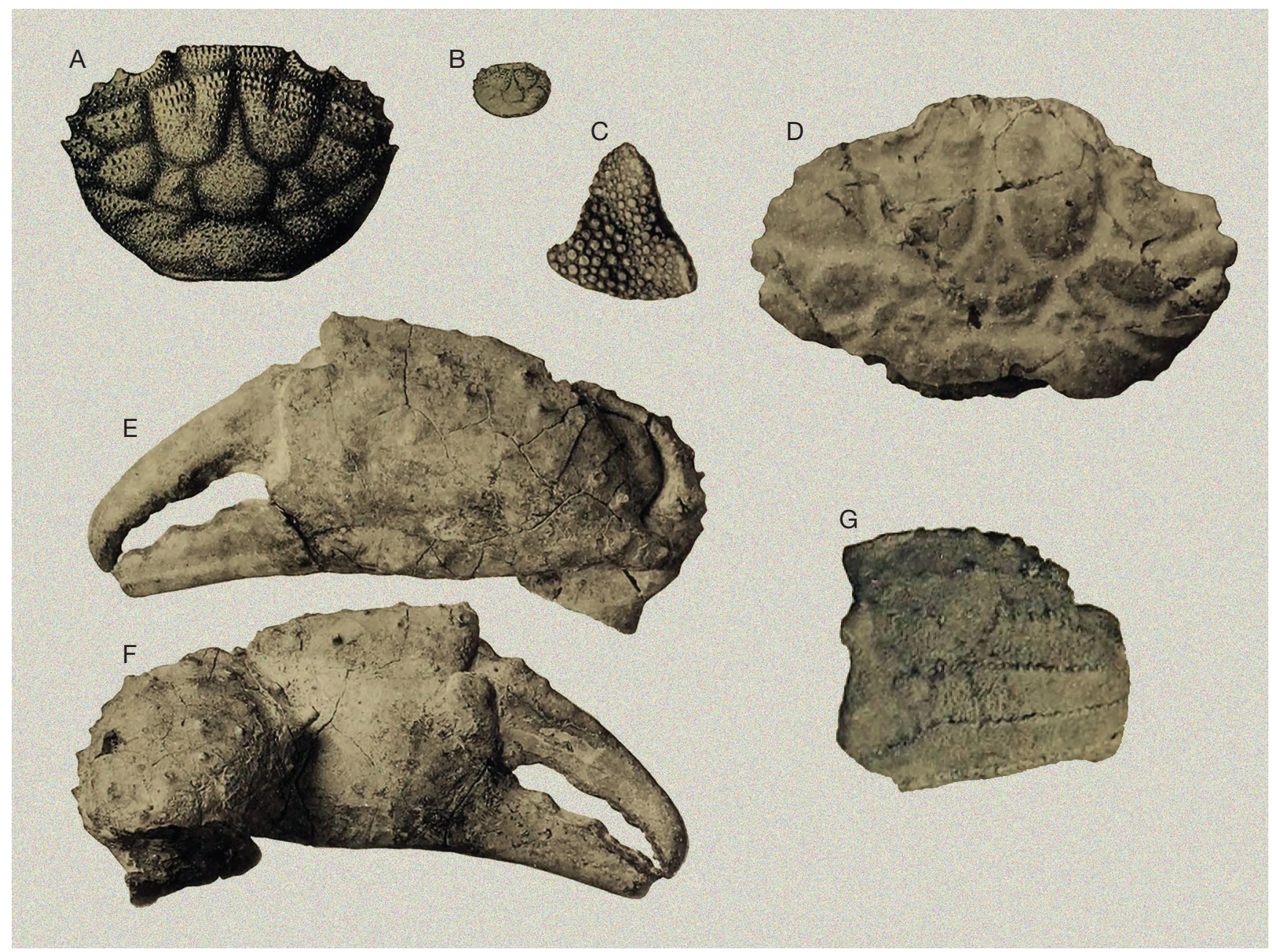

FIG. 6. - Digital reproduction of the figures from Couffon (1908) with the original nomenclature: A-D, Titanocarcinus pulchellus Al. Milne-Edwards, 1865 (sic); E, F, Cancer Sismondae Meyer, 1843? (sic); G, Cancer Deshayesii A. Milne-Edwards, 1865 (sic). Without scale.

tion of its dactyli, does not corresponds with Cancridae chelae (see Nations 1975; Schram \& Ng 2012). Glaessner (1933: $6,7)$ discussed on it and interpreted this chela as Eriphia? sp. An examination of this cheliped would be necessary to a proper identification. A second specimen, a palm of a left chela (Couffon 1908: t. 1, fig. 11; Fig. 6G), was attributed to Cancer deshayesii (synonymous of Lobocarcinus sismondai [see Glaessner 1929]). Indeed, this palm presents the typical cancrid features (cf. Nations 1975; Schram \& Ng 2012) and matches well with those of L. sismondai (see Bonfiglio \& Donadeo 1982: fig. 17). However, as far we know, L. sismondai has not been reported in the Miocene of the European Atlantic (see Collins 2002: 86; Van Bakel et al. 2003). Furthermore, given the great similarity among the palms of the Cancridae, and considering that we have not recognized any carapace remains attributable to that species among the material examined, we prefer to leave this chela tentatively as Lobocarcinus sp.

The two fragments of dactyli attributed by Couffon (1908: 2, pl. 1, fig. 5) to Neptunus aff. monspeliensis (sic) would belong likely to a portunid species, but their fragmentary condition does not allow any specific or even generic attribution. Therefore, we leave them as undetermined portunid.

The crab assemblage present in the Middle-Late Miocene of the 'Faluns' of Anjou-Touraine, represents species of nine families. It shows a clear affinity with Mediterranean and Paratethyan coeval faunas. Indeed, all of the genera reported herein, and even several species such as Calappa praelata, Maja orbignyana, Pilumnus mediterraneus and Xantho cf. moldavicus, are also present in the Mediterranean and Paratethys realms during the Miocene (e.g. Müller 1993; Hyžný 2016). The only exception is Hebertides, which appears to have a North Atlantic affinity, like other Neogene Corystidae, at least in view of the fossil record (e.g. Müller 1984a; Van Bakel et al. 2003, 2009).

\section{CONCLUSIONS}

A complete appraisal of the fossil crustacean fauna of the Middle-Late Miocene of the 'Faluns' of Anjou-Touraine is accomplished for the first time since Couffon (1908). The 
preservation of the specimens, all of them disarticulated, indicates an environment of shallow, agitated waters. This decapod assemblage, clearly dominated by Pilumnus mediterraneus, shows strong affinities with the Miocene Mediterranean-Paratethyan faunas, with which this assemblage shares all the genera here reported, eight in total, with the exception of Hebertides. Thanks to new evidence, the supposed Cenozoic (Miocene) age of Hebertides jurassica is confirmed herein, as well as its possible geographic provenance. Finally, the portunid crab Scylla michelini is transferred again to Necronectes.

\section{Acknowledgements}

We are grateful to Jean Claude Gagnaison for help facilitating access to the collections of the Musée du Savignéen. Sébastien Sage and Valentin Prugneaux kindly donated important specimens described herein. Peter Massicard (ANR11-INBS-0004 Recolnat) provided pictures of comparative specimens. Françoise Marot provided important literature. Javier Luque and George Phillips helped with the review of the English language. We thank Alessandro Garassino and Matúš Hyžný for their accurate and constructive reviews.

\section{REFERENCES}

Artal P. \& Gilles A. 2007. - New Miocene crabs from Pignan (southeast France), in Garassino A., Feldmann R. M. \& Teruzzi G. (eds), $3^{\text {rd }}$ Symposium on Mesozoic and Cenozoic decapod crustaceans. Museo di Storia Naturale du Milano, May 23-25, 2007. Memorie della Società italiana di Scienze Naturali e del Museo cívico di Storia naturale di Milano 35: 37-42.

BACHMAYER F. 1953a. - Die Dekapodenfauna des tortonischen Leithakalkes von Deutsch-Altenburg (Niederösterreich). Mitteilungen der Geologischen Gesellschaft in Wien 44: 237-262.

BACHMAYER F. 1953b. - Zwei neue Crustaceen-Arten aus dem Helvet-Schlier von Ottnang (Oberösterreich). Annalen Des Naturhistorischen Museums in Wien 59: 137-140. https://www. jstor.org/stable/41769069

BACHMAYER F. 1962. - Die Calappiden (Crustacea, Decapoda) aus den tortonischen Ablagerungen des Wiener Beckens. Annalen Des Naturhistorischen Museums in Wien 65, 39-46. https://www. jstor.org/stable/41769719

BaChMaYer F. \& TOllmann A. 1953. - Die Crustaceen-Fauna aus dem tortonischen Leithakalk (Steinbrüche der Firma Fenk) bei Groß-Höflein im Burgenland. Skizzen zum Antlitz der Erde (Kober-Festschrift): 308-314.

Betancort J. F., Lomoschitz A. \& Meco J. 2014. — Mio-Pliocene crustaceans from the Canary Islands, Spain. Rivista Italiana di paleontologia e Stratigrafia 120 (3): 337-349.

Bonfiglio L. \& Donadeo G. 1982. - Cancer sismondai Meyer nel Pliocene di Torre dell'Orso (Puglia) Atti della Società italiana di Scienze Naturali e del Museo civico di Storia naturale di Milano 123: 255-296.

Bouvier E. L. 1899. - Calappa Zurcheri, Crabe nouveau des terrains miocènes de Panama. Bulletin du Muséum d'Histoire naturelle 5: 189-192. https://biodiversitylibrary.org/page/42892478

BROCCHI P. 1883. - Notes sur les crustacés fossiles des terrains tertiaires de la Hongrie. Annales des Sciences géologiques 14 (2): 1-8.

Buge É. 1948. - Les bryozoaires du Savignéen (Helvétien) de Touraine: essai de paléogéographie du Néogène de l'ouest de la France. Muséum national d'Histoire naturelle, Paris, 31 p. (Mémoires du Muséum national d'Histoire naturelle - Nouvelle série ; 27 [3]).
Carvalho A. M. G. DA 1959. - Malacostráceos das formacóes glauconiosas do Miocénico superior do litoral a norte do Cabo Espichel. Boletim do Museu e Laboratório Mineralógico e Geológico da Faculdade de Ciências da Universidade de Lisboa 8 (1): 77-82.

Collins J. S. H. 2002. - A taxonomic review of British decapod Crustacea. Bulletin of the Mizunami Fossil Museum 29: 81-92.

Collins J. S. H. 2014. — Middle Miocene "Badenian” (Langhian) decapod crustaceans from the Retznei quarry, Styrian Basin, Austria. Bulletin of the Mizunami Fossil Museum 40: 29-50.

CoufFON O. 1908. - Sur quelques crustacés des faluns de Touraine et d'Anjou suivi d'un essai de Prodrome des Crustacés podophthalmaires miocènes. La Feuille des jeunes Naturalistes 39: 1-40. https://biodiversitylibrary.org/page/43027551

Couffon O. 1910. - Maïa Orbigniana Millet, in Palaeontologia Universalis. Laval, France, $140 \mathrm{p}$.

Couffon O. 1934. - Précis de Géologie angevine. Imprimerie Centrale, Angers, 195 p.

Courville P. \& Bongrain M. 2003. - Les Pectinidae miocènes des faluns (Ouest de la France). Intérêts biostratigraphiques des associations. Annales de Paléontologie 89: 125-151. https://doi. org/10.1016/S0753-3969(03)00022-3

De Angeli A., Garassino A. \& Pasini G. 2011. - New report of the coral-associated decapods from the Early Messinian (Late Miocene) of Acquabona, Rosignano Marittimo (Toscana, Italy). Atti della Società italiana di Scienze Naturali e del Museo civico di Storia naturale di Milano 152 (2): 107-122.

De Angeli A. \& MARANGON S. 1992. - Necronectes schafferi Glaessner nel Miocene della Sardegna, Italia. Lavori Società Veneziana di Scienze Naturali 17: 175-182.

DE HAAN W. 1833-1850. - Crustacea, in VON SiebOld P. F. (ED.), Fauna Japonica sive Descriptio Animalium, quae in Itinere per Japoniam, Jussu et Auspiciis Superiorum, qui summum in India Batava Imperium Tenent, Suscepto, Annis 1823-1830 Collegit, Notis, Observationibus et Adumbrationibus Illustravit. J. Müller et Co., Leyden, i-xvii, i-xxxi, ix-xvi: 1-243. https://doi.org/10.5962/ bhl.title.124951

Díaz-Medina G., HyŽNÝ M. \& KlompMaker A. A. 2017. - A lithostratigraphic and palaeoenvironmental framework for the late Miocene El Caracolar section (Granada Basin, Betic Cordillera, Spain) and description of decapod crustaceans. Geobios 50: 173-195. https://doi.org/10.1016/j.geobios.2017.04.003

EMmERSON W. D. 2017. - A Guide to, and Checklist for, the Decapoda of Namibia, South Africa and Mozambique. Volume 2. Cambridge Scholars Publishing, Cambridge, 650 p.

FABRICIUS J. C. 1798. - Supplementatione Entomologiae Systematicae. C. G. Proft et Storch, Hafniae, Copenhagen, 572 p.

FORSKÅL P. 1775. - Descriptiones animalium, avium, amphibiorum, piscium, insectorum, vermium; quae in itinere orientali observavit. Petrus Forskål, Mölleri, Hafniae, Copenhagen, 164 p. https:// doi.org/10.5962/bhl.title. 2154

FÖRSTER R. 1979. - Decapod Crustaceans from the Korytnica basin (Middle Miocene; Holy Cross Mountains, Central Poland). Acta Geologica Polonica 9 (3): 253-268.

FriebE J. G. 1987. — Eine Krebben-Fauna aus dem Leithakalk (Badenien) von Wurzing bei Wildon, Steiermark. Mitteilungen des Naturwissenschaftlichen Vereines für Steiermark 117: 57-65.

Froglia C. \& MAnning R. B. 1982. - Notes on Liocarcinus pusillus (Leach) and related species. Quaderni del Laboratorio di Tecnologia della Pesca 3 (2-5): 257-266.

GAGNAISON C. 2012. — Des bernard-l'hermites dans les faluns miocènes de Channay-sur-Lathan (Indre-et-Loire, France). Cossmanniana 14: 67-72.

GAGNAISON C. 2017. — Le site paléontologique du Grand Morier (Pont-Boutard, Indre-et-Loire, France) : contexte géologique et détail biostratigraphique des formations cénozoïques à partir des assemblages de vertébrés fossiles. Geodiversitas 39 (2): 251-271. https://doi.org/10.5252/g2017n2a5 
Gagnaison J. C., Gagnaison C. \& Hartmann J. P. 2009. — Les fossiles d'invertebrés miocènes de la collection de J.-P. Hartmann conservés dans le Musée du Savignéen. Symbioses 23: 1-6.

Gagnaison C., Cabidoche M., Riera R. \& Dechamps M. 2018. The Lower Orleanian Continental Sands from the Savigné-sur-Lathan/ Noyant-sous-le-Lude basin (Anjou-Touraine, France): Sedimentology, Biostratigraphy and Paleoenvironment. Congrès RST, Lille, 22-26 octobre 2018, 1 poster.

Gagnaison C., Guevel B., Xerri S., Sicot J. L., Villeneuve J. M. \& Cossard B. 2012. — La falunière du Tourrelet (Thenay, Loir-et-Cher, France) : nouvelles données sur les vertébrés des sables continentaux du Miocène moyen (Orléanien supérieur: MN5). Revue de Paléobiologie 31 (1): 219-234.

Garassino A. \& NovaTi M. 2001. - Liocarcinus lancetidactylus (Smirnov, 1929) and Platymaia lethaeus (Smirnov, 1929) from the Miocene of N Caucasus (Russia). Atti della Società iltaliana di Scienze naturali e del Museo Civico di Storia naturale di Milano 141 (2): 269-281.

GatT M. \& De Angeli A. 2010. - A new coral-associated decapods assemblage from the Upper Miocene (Messinian) upper Coralline Limestone of Malta (Central Mediterranean). Palaeontology 53 (6): 1315-1348. https://doi.org/10.1111/j.1475-4983.2010.01008.x

GLAESSNER M. 1928. — Die Dekapodenfauna des Österreichischen Jungtertiárs. Jahrbuch der Geologischen Bundesanstalt 78: 161-219.

GLAESSNER M. F. 1929. - Crustacea, Decapoda, in POMPECKJ F. J. (ed.), Fossilium Catalogus. I: Animalia. Part. 41. W. Junk, Berlin, 464 p.

GLAESSNER M. F. 1933. - New Tertiary crabs in the collection of the British Museum. Annals and Magazine of Natural History, Series 10, 12 (67):1-28.

GÓRKA M., STUDENCKa B., JaSIONOWSKI M., HaRA U., WYSOCKA A. \& POBEREZHSKYY A. 2012. — The Medobory Hills (Ukraine): Middle Miocene reef systems in the Paratethys, their biological diversity and lithofacies. Biuletyn Państwowego Instytutu Geologicznego 449: 147-174.

GUINOT D. 1977. - Propositions pour une nouvelle classification des Crustacés Décapodes Brachyoures. Comptes Rendus hebdomadaires des Séances de l'Académie des Sciences, série D, Sciences naturelles 285: 1049-1052. https://gallica.bnf.fr/ark:/12148/ bpt6k5497404n/f355.item

Guinot D., De ANGeli A. \& GARAssino A. 2007a. — Discovery of the oldest eubrachyuran crab from the Middle Jurassic (Bathonian) of Normandy (France), in $3^{\text {rd }}$ Symposium on Mesozoic and Cenozoic Decapod Crustaceans - Museo di Storia Naturale di Milano, May 23-25, 2007. Memorie della Società italiana di Scienze naturali e del Museo civico di Storia naturale di Milano 35 (2): 53-55.

Guinot D., De Angeli A. \& Garassino A. 2007b. - Hebertides jurassica n. gen., n. sp. (Crustacea, Decapoda, Brachyura) from the Middle Jurassic (Bathonian) of Normandy (France). Atti della Società italiana di Scienze naturali e del Museo civico di Storia naturale in Milano 14 (2): 241-260.

HeRbST J. F. W. 1782-1804. — Versuch einer Naturgeschichte der Krabben und Krebse: nebst einer systematischen Beschreibung ihrer verschiedenen Arten. Gottlieb August Lange, Berlin \& Stralsund, 515 p. https://doi.org/10.5962/bhl.title.64679

HYŽNÝ M. 2016. - Diversity and distribution patterns of the Oligocene and Miocene decapod crustaceans (Crustacea: Malacostraca) of the Western and Central Paratethys. Geologica Carpathica 67 (5): 471-494. https://doi.org/10.1515/geoca-2016-0030

HYŽNÝ M., HARZHAUSER M. \& DANNINGER W. 2015. — Decapod Crustacea of the Central Paratethyan Ottnangian Stage (middle Burdigalian): implications for systematics and biogeography. Geologica Carpathica 66 (3): 217-233. https://doi.org/10.1515/geoca-2015-0021

Jagt J. W. M., Van BaKel B. W. M., Guinot D., Fraaije R. H. B. \& Artal P. 2015. - Fossil Brachyura, in CAstro P., Davie P., Guinot D., Schram F. \& von Vaupel Klein J. (eds), Treatise on Zoology - Anatomy, Taxonomy, Biology. The Crustacea, vol. 9, Part C-II, Chapter 71-15. Brill, Leiden/Boston: 847-920. https:// doi.org/10.1163/9789004190832_018
JeRZMAŃSKA A. 1967. - Crabs of the genus Portunus Weber from the Menilite Series of the Carpathians. Annales de la Société géologique de Pologne 37: 539-545. (in Polish, with English summary).

KarasaWA H., SCHWEITZER C. E. \& FeldMANN R. M. 2008. - Revision of the Portunoidea Rafinesque, 1815 (Decapoda: Brachyura) with emphasis on the fossil genera and families. Journal of Crustacean Biology 28 (1): 82-127. https://doi.org/10.1651/07-2882R.1

KeEnan C. P., Davie P. J. F. \& MAnN D. L. 1998. — A revision of the genus Scylla De Haan, 1833 (Crustacea: Decapoda: Brachyura: Portunidae). The Raffles Bulletin of Zoology 46 (1): 217-245.

KocH M. \& DUURIš Z. 2016. — Notes on distribution of some portunid crabs in the Mediterranean Sea (Decapoda: Brachyura: Portunidae). Acta Musei Silesiae, Scientiae Naturales 65: 117-128. https://doi.org/10.1515/cszma-2016-0015

LAMARCK J. B. 1801. - Système des animaux sans vertèbres, ou Tableau général des classes, des ordres et des genres de ces animaux [...] précédé du discours d'ouverture du Cours de Zoologie donné dans le Muséum national d'Histoire naturelle, l'an 8 de la République. Déterville, Paris, 432 p. https://doi.org/10.5962/bhl.title.14255

Latreille P. A. 1802. - Histoire naturelle, générale et particulière des Crustacés et des Insectes. Ouvrage faisant suite aux CEuvres de Leclerc de Buffon, et Partie du Cours complet d'Histoire naturelle rédigé par C. S. Sonnini, Membre de plusieurs Sociétés savantes. F. Dufart, Paris, vol. 3: 1-468. https://doi.org/10.5962/bhl.title.15764

LATREILlE P. A. 1810. - Considérations générales sur l'ordre naturel des animaux composant les classes des Crustacés, des Arachnides, et des Insectes; avec un tableau méthodique de leur genres, disposés en familles. Paris, 444 p. https://doi.org/10.5962/bhl.title.39620

LEACH W. E. 1814. - Crustaceology, in BREWSTER D. (ed.), The Edinburgh Encylopaedia 7: 383-437. https://biodiversitylibrary. org/page/37187640

LEACH W. E. 1815. - The Zoological Miscellany; being Descriptions of New, or Interesting Animals, Illustrated with Coloured Figures, Drawn from Nature, in NoDDER R. P. et al. (eds). E. Nodder \& Son, London, vol. 2: 145-154. https://doi.org/10.5962/bhl.title.41372 LeCoINTRE G. 1947. - Géologie régionale de la France. 4: La Touraine. Actualités scientifiques et industrielles 1027: 1-240.

LinNaeus C. 1758. - Systema Naturae per Regna Tria Naturae, Secundum Classes, Ordines, Genera, Species, cum Characteribus, Differentiis, Synonymis, Locis, Editio decima, reformata. Tomus 1. Laurentii Salvii, Holmiae iii, 828 p. https://doi.org/10.5962/ bhl.title. 542

Linnaeus C. 1761. — Fauna Suecica sistens Animalia Sueciae Regni: Mammalia, Aves, Amphibia, Pisces, Insecta, Vermes. Distributa per classes et ordines, genera et species, cum differentiis specierum, synonymis auctorum, nominibus incolarum, locis natalium, descriptionibus Insectorum. Editio altera, auctior, Stockholmiae, $578 \mathrm{p}$ https://doi.org/10.5962/bhl.title.46380

LÖRENTHEY I. 1897. — Adatok Magyarország harmadkorú rák faunájához. Mathematikai és Természettudományi Érttesitö 15: 149-169

LÖRENTHEY I. 1898a. — Beitrage zur Decapodenfauna des ungarischen Tertiárs. Mathematische und naturwissenschaftliche Berichte aus Ungarn 14: 92-115. https://biodiversitylibrary.org/page/31025629

LŐRENTHEY I. 1898b. — Adatok Magyarország harmadkorú rákfaunájához. Mathematikai és Természettudományi Érttesito" 27 (2): 103-271.

LŐRENTHEY I. 1898c. — Beitrage zur Decapodenfauna des Ungarischen Tertiárs. Természetrajzi füzetek 21: 1-133. https://biodiversitylibrary.org/page/30765126

LŐRENTHEY E. \& BEURlen K. 1929. - Die fossilen Decapoden der Lander der Ungarischen Krone. Geologica Hungarica, Series Palaeontologica 3: 1-420.

Luque J., Schweitzer C. E., Santana W., Portell R. W., Vega F. J. \& KlOMPMAKer A. A. 2017. - Checklist of fossil decapod crustaceans from tropical America. Part I: Anomura and Brachyura. Nauplius 25: e2017025. https://doi.org/10.1590/23582936e2017025 https://doi.org/10.1590/2358-2936e2017025 
MaClEaY W. S. 1838. - On the Brachyurous Decapod Crustacea Brought from the Cape by Dr. Smith, in SMITH A. (ed.), Illustrations of the Annulosa of South Africa; Consisting Chiefly of Figures and Descriptions of the Objects of Natural History Collected During an Expedition into the Interior of South Africa, in the Years 1834, 1835, and 1836; fitted out by "The Cape of Good Hope Association for Exploring Central Africa...”. Vol. 3. Smith, Elder and Company, London: 53-71. https://biodiversitylibrary.org/page/42776618

MarRas G. \& Ventura G. 1991. - Crostacei decapodi del Miocene di Sassari (Sardegna nord-occidentale). Bollettino della Società Sarda di Scienze Naturali, Sassari 28: 105-119.

Millet P. A. 1854. - Paléontologie de Maine et Loire. Cosnier et Lachèse, Angers, 187 p. https://doi.org/10.5962/bhl.title.15140

Millet de la TurTaudière P. A. 1865. - Paléontographie ou Description des fossiles nouveaux du terrain tertiaire marin ou terrain miocène supérieur du département de Maine-et-Loire (Supplément). Indicateur de Maine et Loire. Cosnier et Lachèse, Angers, vol. 2, 616 p.

MiLNE-EDWARDS A. 1860a. - Histoire des Crustacés podophthalmaires fossiles. Annales des Sciences naturelles, Zoologie, 4eime série, 14: 129-293. https://biodiversitylibrary.org/page/29145258

Milne-EDWARDS A. 1860b. - Monographie des Thalassiens fossiles. Annales des Sciences naturelles, Zoologie, 4ème série, 14: 294-358. https://biodiversitylibrary.org/page/29145425

MilnE-EDWARDS A. 1861. - Études zoologiques sur les Crustacés récents de la famille des Portuniens. Archives du Muséum national d'Histoire naturelle 10: 309-421. https://biodiversitylibrary.org/ page/ 11097278

Milne-Edwards A. 1863. - Monographie des Crustacés fossiles de la famille des Cancériens. Annales des Sciences naturelles, Zoologie, 4ìme série, 20: 273-324. https://biodiversitylibrary.org/ page/29128628

MilnE-EdWARDS A. 1864. - Monographie des Crustacés fossiles de la famille des Cancériens. Annales des Sciences naturelles, Zoologie, Sème série 1:31-88, pls 1-10. https://biodiversitylibrary. org/page/29128796

MiLNE-EDWARDS A. 1881. - Note sur quelques Crustacés fossiles des environs de Biarritz. Annales des Sciences géologiques 11 (2): 1-8.

Müller P. 1974a. - Decapoda (Crustacea) fauna a budapesti miocénből 1. (Les faunes de Crustacés Décapodes des calcaires miocènes de Budapest.). Földtani közlöny 104 (1): 119-132.

Müller P. 1974b. - Decapoda (Crustacea) fauna a budapesti miocénből 2. (Faune de Décapodes [Crustacés] du Miocène de Budapest). Földtani közlöny 104 (3): 275-287.

MÜLLER P. 1976a. - Decapoda (Crustacea) fauna a budapesti miocénből 3. (Faune de Décapodes [Crustacés] du Miocène de Budapest). Földtani közlöny 105 (4): 506-512.

MülleR P. 1976b. - Decapoda (Crustacea) fauna a budapesti miocénből 4. (Faune de Décapodes [Crustacés] du Miocène de Budapest). Földtani közlöny 106 (2): 149-160.

MÜlleR P. 1979. - Decapoda (Crustacea) fauna a budapesti miocénből 5. (Faune de Décapodes [Crustacés] du Miocène de Budapest). Földtani közlöny 108 (3): 272-312.

MÜller P. 1984a. — Decapod Crustacea of the Badenian. Geologica Hungarica, Series Palacontologica 42: 25-317.

MÜLLER P. 1984b. - Messinian and older decapods from the Mediterranean with description of two new species. Annales géologiques des Pays helléniques 32: 25-34.

MỨlLER P. 1993. - Neogene decapod crustaceans from Catalonia. Scripta Musei Geologici Seminarii Barcinonensis 225: 1-39.

MüLleR P. 1996. — Middle Miocene Decapod Crustacea from southern Poland. Prace Muzeum Ziemi, Prace paleozoologiczne 43: 3-14.

MÜller P. 1998. - Crustacea Decapoda, in FlügEL H. W. (ed.), Catalogus Fossilium Austriae. Verlag der Österreichischen Akademie der Wissenschaften: 1-48.

NG P. K. L., Guinot D. \& Davie P. J. F. 2008. — Systema Brachyurorum: Part I. An annotated checklist of extant brachyuran crabs of the world. The Raffles Bulletin of Zoology, Supplement 17: 1-286.
Ortmann A. E. 1893. - Die Decapoden-Krebse des Strassburger Museums, mit besonderer Berücksichtigung der von Herrn Dr.Döderlein bei Japan und bei den Liu-Kiu-Inseln gesammelten und zur Zeit im Strassburger Museum aufbewahrten Formen. VII. Theil. Abtheilung: Brachyura (Brachyura genuina Boas) II. Unterabtheilung: Cancroidea, 2. Section: Cancrinea, 1. Gruppe: Cyclometopa. Zoologische Jahrbücher. Abteilung für Systematik, Geographie und Biologie der Thiere 7 (3): 411-495. http://www. biodiversitylibrary.org/page/39199489

Ossó A. \& Stalennuy O. 2011. - Description of the first fossil species of Bathynectes (Brachyura, Polybiidae) in the Badenian (middle Miocene) of the Medobory Hills (Ukraine, Central Paratethys), with remarks on its habitat ecology. Treballs del Museu de Geologia de Barcelona 18: 37-46. https://doi.org/10.32800/ tmgb.2011.18.0037

Nations J. D. 1975. - The genus Cancer (Crustacea: Brachyura): systematics, biogeography and fossil record. Natural History Museum of Los Angeles County Science Bulletin 23: 1-104.

Pasini G., De ANGeli A. \& GARAsSino A. 2012. - Calappa praelata Lőrenthey in Lörenthey \& Beurlen, 1929 (Decapoda, Brachyura, Calappidae) from the Middle Miocene of Tresnuraghes (Oristano, Sardegna, Italy). Atti della Società italiana di Scienze naturali e del Museo civico di Storia naturale in Milano 153 (1): 135-140.

PAUCĂ M. 1929. — Zwei neue fossile Decapoden aus den Oligozänen Clupea crenata Schiefern von Susläneski-Muscel und über die Bildung der Menilitschiefer. Bulletin de la Section scientifique de l'Académie roumaine 12: 4, 5, 40-44.

RADWAŃSKI A., GÓRKA M. \& WysOCKA A. 2006. — Middle Miocene coralgal facies at Maksymivka near Ternopil (Ukraine): a preliminary account. Acta Geologica Polonica 56: 89-103.

RAFINESQUE C. S. 1815. - Analyse de la Nature ou Tableau de l'Univers et des Corps organisés. Jean Barravecchia, Palerme, 230 p. https://doi.org/10.5962/bhl.title.106607

Rathbun M. J. 1918. - Decapod crustaceans from Panama, in VAUGHAN T. W. (ed.), Contributions to the geology and paleontology of the Canal Zone, Panama and geologically related areas in Central America and the West Indies. United States National Museum Bulletin 103: 123-184. http://www.biodiversitylibrary.org/page/32168508

SAinT LAURENT M. DE 1980. - Sur la classification et la phylogénie des Crustacés Décapodes Brachyoures. I. Podotremata Guinot, 1977 et Eubrachyura sect. nov. Comptes Rendus hebdomadaires des Séances de l'Académie des Sciences, série D, Sciences naturelles, 290: 1265-1268. https://gallica.bnf.fr/ark:/12148/ bpt6k57740656/f111.item

SAmOuElle G. 1819. - The Entomologist's Useful Compendium; or an Introduction to the Knowledge of British Insects, Comprising the Best Means of Obtaining and Preserving them, and a Description of the Apparatus Generally Used; Together with the Genera of Linné, and the Modern Method of Arranging the Classes Crustacea, Myriapoda, Spiders, Mites and Insects, from their Affinities and Structure, According to the Views of Dr. Leach. T. Boys, London, 496 p. https://doi.org/10.5962/bhl.title.34177

Schram F. R. \& NG P. K. L. 2012. - What is Cancer? Journal of Crustacean Biology32 (4): 665-672. https://doi.org/10.1163/193724012X640650 https://doi.org/10.1163/193724012X640650

Schweitzer C. E., Artal P., van Bakel B., Jagt J. W. M. \& KarasaWA H. 2007. - Revision of the genus Titanocarcinus (Decapoda: Brachyura: Xanthoidea) with two new genera and one new species. Journal of Crustacean Biology 27 (2): 278-295. https://doi.org/10.1651/S-2713.1

Schweitzer C. E., Feldmann R. M., Garassino A., Karasawa H. \& SCHWEIGERT G. 2010. — Systematic list of fossil decapod crustacean species. Crustaceana Monograph 10: 1-1222. https://doi. org/10.1163/ej.9789004178915.i-222

Schweitzer C. E., Feldmann R. M. \& LAZǍr I. 2009. — Fossil Crustacea (excluding Cirripedia and Ostracoda) in the University of Bucharest Collections, Romania, including two new species. Bulletin of the Mizunami Fossil Museum 35: 1-14. 
Schweitzer C. E., Iturralde-Vinent M., Hetler J. H. \& Vélez-Juarbe J. 2006. - Oligocene and Miocene decapods (Thalassinidea and Brachyura) from the Caribbean. Annals of Carnegie Museum 75 (2): 111-136. https://doi.org/10.2992/00 97-4463(2006)75[111:OAMDTA]2.0.CO;2

SMIRNOV V. P. 1929. - Decapoda of the fish beds at Black river in the vicinity of Vladikavkaz. (Decapoda iz rybnykplastov na Chernoy rechke v okrastnostyakh Vladikavkaza). Arbeiten der Nord-Kaukasischen Assoziation Wissenschaftlicher Institute 59: 1-49 (in Russian).

SolÉ J. \& VIA L. 1989. — Crustacis Decàpodes fòssils dels Països Catalans (Recopilació i actualització des de 1855 a 1988). Batalleria 2: 23-42.

STIMPSON W. 1871. - Preliminary report on the Crustacea dredged in the Gulf Stream in the Straits of Florida by L.F. de Pourtales, Assist. U.S. Coast Survey. Part I. Brachyura. Bulletin of the Museum of Comparative Zoology at Harvard College 2: 109-160. https:// biodiversitylibrary.org/page/6313618

TAYLOR P. D. 2012. — Two Tales of 'Un-Jurassic' Fossils. Bulletin International Bryozoology Association 8 (2): 9-12.

TaYlor P. D., Breton G., Guinot D., De Angeli A. \& GARAsSino A. 2012. - The Cenozoic age of the supposed Jurassic crab Hebertides jurassica Guinot, De Angeli \& Garassino, 2007 (Crustacea, Decapoda, Brachyura). Atti della Società italiana di Scienze naturali e del Museo civico di Storia naturale in Milano 153 (1): 71-83.

Temey I. 1996. - Le Néogène de Touraine: approche environnementale et paléogéographique des faluns du bassin de Noyant-Savigné (Indre-et-Loire et Maine-et-Loire, France). Mémoire d'Ingénieur géologue, Institut géologique Albert-de-Lapparent, Cergy-Pontoise 73: 1-292 (unpublished).

Trivedi J. N. \& VAchHrajani K. D. 2013. - Taxonomic account of genus Scylla (de Haan, 1833) from Gujarat State, India with two new records of species. Arthropods 2 (4): 159-171.
Van Bakel B. W. M., Jagt J. W. M., Fraaije R. H. B. \& Wille E. R. H. 2003. - Piacenzian (Pliocene) decapod crustacean faunules from northwest Belgium. Bulletin of the Mizunami Fossil Museum 30: 97-108.

Van Bakel B. W. M., Jagt J. W. M., Artal P. \& Fraaije R. H. B. 2009. - Harenacorystes johanjansseni, a new Pliocene crab (Crustacea, Decapoda) from the Netherlands, and notes on Miocene-Pliocene corystoid crabs from the North Sea Basin. Bulletin of the Mizunami Fossil Museum 35: 79-85.

VAN STRAELEN V. 1937. — Sur quelques crabes du Sahélien moyen des environs d'Oran (Algérie). Bulletin de la Société géologique de France, sér. 5, t. 6, vol. 30: 473-480.

Veiga Ferreira O. DA 1958. — Descoberto de "Calappa heberti" no Tortoniano do Penedo. Comunicaçóes dos Serviços Geológicos de Portugal 42: 203-207.

VIA L. 1932. - Els crancs fòssils del Terciari de Catalunya. Butlletí de la Institució Catalana d'Història Natural 32 (4): 131-146.

Vía L. 1941. — Los cangrejos fósiles de Cataluña. Boletín del Instituto Geológico y Minero de España 55: 3-73.

VIA L. 1988. - Els decàpodes, in Història Natural dels Països Catalans. Fundació Enciclopèdia Catalana, Barcelona, vol. 15 (Registre fossil): 351.

WEBER F. 1795. - Nomenclator entomologicus secundum Entomologiam Systematicum ill. Fabrici, in adjectis speciebus recens detectis et varietatibus. Chilonii and Hamburgi, C.E. Bohn, $171 \mathrm{p}$.

Wysocka A., RadWAŃSKi, A., GóRKa M., Babel M., RaDWAŃSKA U. \& ZŁOTNIK M. 2016. - The Middle Miocene of the Fore-Carpathian Basin (Poland, Ukraine and Moldova). Acta Geologica Polonica 66: 377-379. https://doi.org/10.1515/ agp-2016-0017

YANAKEVICH A. N. 1977. - Middle Miocene reefs of Moldavia. Stiinca, Kishinev, 116 p (in Russian). 